This is the peer reviewed version of the following article: González de Andrés E, Blanco JA, Imbert JB, Guan BT, Lo Y-H, Castillo FJ. ENSO and NAO affect long-term leaf litter dynamics and stoichiometry of Scots pine and European beech mixedwoods. Glob Change Biol. 2019;25:3070-3090, which has been published in final form at https://doi.org/10.1111/gcb.14672. This article may be used for non-commercial purposes in accordance with Wiley Terms and Conditions for Use of Self-Archived Versions.

Post-print of the article Global Change Biology 2019;25:3070-

3090. DOI: 10.1111/gcb.14672

Running head: Links between global climate and tree litter

\title{
ENSO and NAO affect long-term leaf litter dynamics and stoichiometry of Scots pine and European beech mixedwoods
}

Ester González de Andrés ${ }^{1}$, Juan A. Blanco ${ }^{1, *}$, J. Bosco Imbert ${ }^{1}$, Biing T. Guan ${ }^{2}$, Yueh-Hsin Lo $^{1}$, Federico J. Castillo ${ }^{1}$

${ }^{1}$ Departamento de Ciencias, Universidad Pública de Navarra, Campus de Arrosadía, Pamplona, Navarra, 31006, Spain.

${ }^{2}$ School of Forestry and Resource Conservation, National Taiwan University, Taipei, 10617, Taiwan, Republic of China

\section{Correspondence:}

Juan A. Blanco, Departamento de Ciencias, Universidad Pública de Navarra, Campus de Arrosadía, Pamplona, Navarra, 31006, Spain.

E-mail: juan.blanco@ unavarra.es

Phone: (+34) 94816 9859; 
Key words: leaf litter, nutrient cycling, ensemble empirical mode decomposition (EEMD), Fagus sylvatica, nutrient limitation, Pinus sylvestris, Pyrenees, stoichiometry, structural equation model (SEM)

\section{PRIMARY RESEARCH ARTICLE}

\section{ABSTRACT}

Litterfall dynamics (production, seasonality and nutrient composition) are key factors influencing nutrient cycling. Leaf litter characteristics are modified by species composition, site conditions and water availability. However, significant evidence on how large-scale, global circulation patterns affect ecophysiological processes at tree and ecosystem level remains scarce due to the difficulty in separating the combined influence of different factors on local climate and tree phenology. To fill this gap, we studied links between leaf litter dynamics with climate and other forest processes, such as tree-ring width (TRW) and intrinsic water-use efficiency (iWUE) in two mixtures of Scots pine (Pinus sylvestris L.) and European beech (Fagus sylvatica L.) in the south-western Pyrenees. Temporal series (18 years) of litterfall production and elemental chemical composition were decomposed following the ensemble empirical mode decomposition (EEMD) method and relationships with local climate, large-scale climatic indices, TRW and Scots pine's iWUE were assessed. Temporal trends in $\mathrm{N}: \mathrm{P}$ ratios indicated increasing $\mathrm{P}$-limitation of soil microbes, thus affecting nutrient availability, as the ecological succession from a pine-dominated to a beech-dominated forest took place. A significant influence of large-scale patterns on tree-level ecophysiology was explained through the impact of the North Atlantic Oscillation (NAO) and El Niño - Southern Oscillation (ENSO) on water availability. Positive NAO and negative ENSO were related to dry conditions and, consequently, to early needle shedding and increased N:P ratio of both species. Autumn storm activity appears to be related to premature leaf abscission of European beech. Significant cascading effects from large-scale patterns on local weather influenced pine TRW and iWUE. These variables also responded to leaf stoichiometry fallen three years prior to tree-ring formation. Our results provide evidence of the cascading effect that 
variability in global climate circulation patterns can have on ecophysiological processes and stand dynamics in mixed forests. 


\section{INTRODUCTION}

Studying the mechanisms that regulate nutrient transfer between different ecosystem compartments may provide insights into nutrient cycling and limitation (Reed et al., 2012; Lang et al., 2016). Leaf litter constitutes (together with root turnover) a major proportion of nutrient cycling between plants and soils (Prescott, 2002), and therefore it reflects constraints on internal fluxes of carbon $(\mathrm{C})$ and key elements such as nitrogen $(\mathrm{N})$, phosphorus $(\mathrm{P})$ and potassium (K) at the ecosystem scale (Vitousek, 1982; McGroddy et al., 2004; ZechmeisterBoltenstern et al., 2015). N:P:K stoichiometry can be associated with important ecological processes and ecosystem traits, such as ecosystem composition and diversity (Güsewell et al., 2005), the ability of trees to adapt to environmental stresses (Sardans et al., 2013; Sardans et $a l ., 2017$ ), or composition of decomposer communities and litter decomposition rates (Berg \& McClaugherty 2003, Güsewell \& Gessner 2009, Mooshammer et al., 2014). One of the most widespread hypotheses in ecological stoichiometry is the growth rate hypothesis, which states that organisms must increase the relative allocation of P to P-rich ribosomal RNA to meet the demands for protein synthesis required for rapid growth, which is possible under low N:P ratios in the environment (Sterner \& Elser, 2002). The link of N:P ratios with anabolic metabolism has also been reported (Rivas-Ubach et al., 2012), suggesting that in more climate-favourable conditions for anabolic metabolism, plants would make a more thorough use of $\mathrm{N}$ and $\mathrm{P}$ prior to leaf litter abscission, and therefore litter would have higher $\mathrm{N}: \mathrm{P}$ ratios. This hypothesis has had consistent support in freshwater ecosystems (Sardans et al., 2012b, and citations therein). However, in complex terrestrial plants such as trees those relationships remain inconclusive.

Decomposition and nutrient mineralization rates are driven by multiple factors, being the most important soils, climate, decomposer community, and litter quality (Berg \& McClaugherty, 2003; Parton et al., 2007). In two global meta-analyses, litter quality (stoichiometry) was identified as the most important factor controlling decomposition rates and thus the resulting nutrient release into the soil (Cornwell et al., 2008; Zhang et al., 2008). The consumer-driven nutrient recycling theory predicts that the balance between litter stoichiometry and microbial element use efficiency directly determines nutrient recycling ratios (Sterner \& Elser, 2002). Unlike plants, soil microbes are largely homeostatic in terms of C:N:P stoichiometry (Xu et al., 2013; Li et al., 2014). This means that variable resource stoichiometry has little or no effect on microbial biomass stoichiometry due to physiological regulation (Sterner \& Elser, 2002). Such regulation mainly includes the control of element use 
efficiencies and the production of extracellular $\mathrm{C}$-, $\mathrm{N}$ - and $\mathrm{P}$ - acquiring enzymes (Mooshammer et al., 2014). The stoichiometric imbalance between litterfall and microbial communities results in microbial activity limitation by a particular nutrient, and thus its immobilization in microbial biomass. Therefore, leaf litter nutrients, particularly $\mathrm{N}$ and $\mathrm{P}$, strongly and positively affect decomposition rates due to the high nutrient demands of microbial decomposers to build and maintain biomass (Conrwell et al., 2008; ZechmeisterBoltenstern et al., 2015).

Leaf litter quality is directly related to nutrient concentration in green leaves and the resorption processes during senescence (Killingbeck, 1996; Kobe et al., 2005). There are substantial differences among species in total plant stoichiometry (Nitschke et al., 2017), and nutrient composition of green leaves (Sardans et al., 2015) and leaf litter (Staelens et al., 2011; Yuan \& Chen, 2009a; Kang et al., 2010). Hence, forest species composition and canopy structure are pivotal drivers of decomposition and nutrient release. Mixed-species forests are increasingly receiving attention as they are considered more resistant to disturbances and extreme events (Jactel et al., 2017) and may provide ecosystem goods and services more effectively than pure stands (Gamfeldt et al., 2013; Duffy et al., 2017). Over recent decades, natural or managed growth of European beech (Fagus sylvatica L.) under Scots pine (Pinus sylvestris L.) canopy has progressively resulted in mixed stands. Although the scientific knowledge on the structure and functioning of this species mixture is quickly accruing (e.g. Pretzsch et al., 2015; Metz et al., 2016; Barbeito et al., 2017; González de Andrés et al., 2017; González de Andrés et al., 2018; Del Río et al., 2017), little is known about its litterfall dynamics and nutrient cycling. Rothe \& Binkley (2001) reviewed multiple nutritional interactions in tree species mixtures regarding foliar nutrition, soil nutrient supply, and nutrient input rates. Primicia et al. (2014) and Urbina et al. (2017) found effects of interspecific competition on resorption efficiency. Recently, Nickmans et al. (2017) have described a significant effect of neighbour species identity on leaf nutrient content. Furthermore, an effect of tree species richness on decomposition rates has been identified (Talkner et al., 2009; Joly et al., 2017). Consequently, nutrient cycling and limitation in mixed-species forests cannot be extrapolated from those of monospecific stands.

Climate is also an important factor on litter decomposition. Current evidence of climate variations effects on litter quality is mostly indirect (García-Palacios et al., 2013). Year-toyear variations in climate and extreme weather events such as droughts or storms can alter litter production’s dynamics and composition (Pausas et al., 1994; Yuan \& Chen, 2009a). 
Variations in leaf litter production have been explained by air temperature (Martínez-Alonso et al., 2007), rainfall (Lehtonen et al., 2008), soil temperature and moisture (Blanco et al., 2006), actual evapotranspiration (Berg \& Meentemeyer, 2001) or wind speed and early frost events (Portillo-Estrada et al., 2013), among others. Climate can also substantially influence seasonal litterfall patterns (Reich \& Borchert, 1984; Wright \& Cornejo, 1990; Portillo-Estrada et al., 2013; Zhang et al., 2014), thereby influencing soil microbial activity and nutrient cycles. Because of modifications of leaf phenology and fall kinetics, there may be strong inter-annual differences in nutrients of senescent leaves (Killingbeck et al., 1990; Del Arco et al., 1991; Escudero et al., 1992; Niinemets \& Tamm, 2005).

The assessment of climate-litterfall relationships has been traditionally focused on locally measured climatic components, but large-scale climate patterns can partially capture the complexity and temporally variable associations between local climate and ecological processes and give an insight on the underlying mechanisms (Stenseth et al., 2002; Stenseth et al., 2003; Hallet et al., 2004). Dominant climatic teleconnections account for major variations in local weather and climate (Stenseth et al., 2002; Gámiz-Fortis et al., 2011) since climate oscillations (e.g. North Atlantic Oscillation (NAO), or El Niño - Southern Oscillation (ENSO) are related to changes in ocean temperatures and global atmospheric phenomena (Hurrell, 1995). The ability of large-scale indices to outperform proxies of local climatic conditions in explaining variation in ecological processes has been demonstrated in plant phenology (Post \& Stenseth, 1999; Guan, 2014), and tree growth (Piovesan \& Schirone, 2000; Camarero, 2011; Rozas et al., 2015; Lo et al., 2017; Madrigal-González et al., 2018). Nevertheless, to the best of our knowledge no research has analysed the effect of global atmospheric-oceanic circulation patterns on leaf litter quantity and quality dynamics.

Understanding productivity limitations imposed by nutrient availability, in which leaf litter dynamics play a key role, is increasingly important for forecasting forest ecosystem responses to global change (Sardans et al., 2017). Using one of the longest records on litterfall production and composition in mixedwoods (18 years), available from two mixed Scots pine - European beech forests of contrasting climatic and fertility characteristics in the southwestern Spanish Pyrenees, our objectives were: (1) to estimate possible trends in ecosystem nutrient limitation using leaf litter nutrient concentration and stoichiometry series as they may constraint further decomposition and nutrient release; (2) to assess the relationships between leaf litter dynamics and trees' performance regarding water-use efficiency and secondary growth; and (3) to evaluate the influence of local climate and large-scale circulation patterns 
on leaf litter production and nutrient composition in order to improve our knowledge of environmental controls of biogeochemical cycling at the ecosystem level. We hypothesize that: (1) leaf litter stoichiometry influences secondary growth of Scots pine; and (2) change in water availability as the result of large-scale climate oscillations influences leaf litter quantity and quality.

\section{MATERIAL AND METHODS}

\section{Study area and climatic data}

The study area is located in the south-western Pyrenees, northern Spain (province of Navarre) (Supporting information Fig. S1). Two contrasting sites were used: a sub-xeric site located at low elevation with a cool and wet Mediterranean climate (MED site), and a mesic site situated at high elevation and characterized by cold-wet continental climate (CONT site). Further information on site characteristics is provided in Table 1. Data describing soil characteristics were obtained by digging soil pits in the year 2000 and then collecting 3-5 soil samples of the top mineral soil per plot $(\sim 13 \mathrm{~cm}$, corresponding approximately with the Ahorizon at both sites) 11 times at irregular intervals during the 2000-2017 period. Main soil chemical features are shown in Table 2.

Climatic data for the period 2000-2017 were obtained from the nearest weather stations to each site. Monthly mean temperature and total precipitation for the period 2000-2017 for each study site was transformed into the more biologically meaningful standardized precipitation evaporation index (SPEI) (Vicente-Serrano et al., 2010). SPEI calculation at time scales of 1 and 3 months was conducted using the SPEI package for R software (Beguería \& Vicente-Serrano, 2017). Further information on climate data collection and transformation can be found in the Supporting information.

In order to identify the responses of local climate and leaf litter dynamics to large-scale circulation patterns, we considered two monthly large-scale climatic indices. The NAO represents the north-south gradient in atmospheric pressure between the subtropical Atlantic and the Arctic oceans; its fluctuations are of the greatest amplitude during the cold season months (Osborn 2011). ENSO describes the atmosphere-ocean interactions throughout the tropical Pacific Ocean and represents Earth's strongest inter-annual climate variation affecting a wide geographic area (Stenseth et al., 2003). In this study, we focused on ERSSTv5 
NINO3.4 $\left(5^{\circ} \mathrm{N}-5^{\circ} \mathrm{S}, 120^{\circ} \mathrm{W}-170^{\circ} \mathrm{W}\right.$; Climate Prediction Center, NOAA, http://www.cpc.noaa.gov/data/indices).

\section{Litterfall sampling}

Three unmanaged plots ( $30 \mathrm{~m}$ x $40 \mathrm{~m}$ ) were set up at each study site. Aboveground litterfall was collected with nine circular traps ( $0.6 \mathrm{~m}$ diameter and $1 \mathrm{~m}$ height) randomly distributed in each plot. A conical plastic mesh was attached to each structure $(1.5 \mathrm{~mm}$ mesh size, $0.5 \mathrm{~m}$ depth). Litterfall collection was conducted over an 18-year period (2000 - 2017). Every trap was emptied at the beginning of August. Litterfall samples were collected during the first week of each month from September to December at the Mediterranean site and from September to November at the continental site (heavy snowfalls commonly prevented litter collection at this site in December). This period was selected as it comprises the main aboveground litterfall peak of pine needles and beech leaves at the study sites (Blanco et al., 2006). Samples were air dried for $24 \mathrm{~h}$, then dried at $70{ }^{\circ} \mathrm{C}$ in an oven to constant weight. Samples were weighed on a precision scale and separated into five fractions: Scots pine needles, European beech leaves, leaves of other broadleaf species, pine branches, and miscellaneous (bark, cones, beechnuts, buds, inflorescences, etc.).

Leaf litter samples (pine needles and beech leaves) were pooled by plot and month and grounded through a 1-mm sieve (MF-10, IKA). Total nitrogen concentration ([N]) in leaf litter was determined by the dry combustion Dumas method (Matejovic 1993) using a TRUSPEC CN628 elemental analyzer (LECO Corporation, MI, USA). Concentrations of phosphorus ([P]) and potassium ([K]) were measured using inductively coupled plasma emission spectrometry (ICP-ICAP 6500 DUO Thermo, England), after acid digestion $\left(\mathrm{HNO}_{3}-\mathrm{H}_{2} \mathrm{O}_{2} 4: 1\right)$ in a microwave. Stoichiometric N:P, N:K and P:K ratios were expressed as mass ratios (g element/g element).

\section{Scots pine radial growth and water-use efficiency}

At each location, we randomly chose eight dominant and co-dominant pine trees per plot $(n=50)$. Selected trees were sampled at breast height perpendicular to the maximum slope using a Pressler increment borer. Tree coring was carried out in the spring of 2014. Two complete radii were extracted from each tree. Cores were air dried, glued onto wooden mounts, and sanded until tree rings were clearly visible (Fritts, 2001). All samples were visually cross-dated using the identification of signature years. Tree-ring width (TRW) was 
measured to a precision of $0.01 \mathrm{~mm}$ using a LINTAB measuring device (Frank Rinn, Heidelberg, Germany). Cross-dating was further validated using the COFECHA software, which calculates moving correlations among individual tree series (Holmes, 1983). For each tree, measurements from the two cores were averaged.

We used ${ }^{13} \mathrm{C} /{ }^{12} \mathrm{C}$ isotope ratios in wood from cross-dated cores as proxies of the intrinsic water-use efficiency (iWUE). Isotopic discrimination in C3 plants is a result of the preferential use of ${ }^{12} \mathrm{CO}_{2}$ over ${ }^{13} \mathrm{CO}_{2}$ during photosynthesis. The two stable $\mathrm{C}$ isotopes are incorporated in varying amounts depending on the ratio between the intercellular $\left(C_{i}\right)$ and the atmospheric $\mathrm{CO}_{2}$ concentrations $\left(C_{a}\right)$, which is determined by stomatal conductance (Farquhar et al., 1982). We randomly chose five trees at each site $(\mathrm{n}=10)$ among trees previously selected for growth analysis. The procedure followed for $\mathrm{C}$ isotopic analysis and iWUE calculation is described in González de Andrés et al. (2018). Scots pine's mean chronologies of TRW and iWUE were constructed by averaging individual tree chronologies at both plot and site scales for the period 2000-2013.

\section{Time series decomposition}

In order to avoid spurious relationships that may arise from strong temporal dependence (Stenseth et al., 2003), we decomposed climatic and leaf litter production and nutrient composition series into a trendless component (TC) and a trend by means of the ensemble empirical mode decomposition (EEMD). EEMD is an improvement of empirical mode decomposition (EMD), an empirical but highly efficient and adaptive method for processing non-linear and non-stationary signals (Huang et al., 1998; Huang \& Wu, 2008). This methodology has been demonstrated to have great potential for chronology development as EEMD-decomposed series correlate with instrumental data better than chronologies obtained following conventional detrending methods (Guan et al., 2018).

EMD aims to decompose a time series into a small number of oscillatory components (intrinsic mode functions, IMFs) and a residual (trend) component (Huang et al., 1998; Huang and $\mathrm{Wu}, 2008)$. The IMFs are sequentially extracted from high to low frequencies using a spline-based iterative sifting process. Once an IMF is extracted, EMD subtracts it from the time series and sifts through the remaining part of the signal to extract the next IMF of lower frequency until it cannot find one. The remaining signal (residual) is either constant, monotonic, or with only one extremum (Huang et al., 1998; Huang \& Wu, 2008). EEMD is a Monte Carlo process in which zero-mean Gaussian white noise is added to each EMD process 
to achieve better signal separation (Wu \& Huang, 2009). Detailed description of EMD and EEMD can be found in Huang et al. (1998), Huang \& Wu (2008) and Wu \& Huang (2009).

EEMD has been successfully applied to dendrochronological (e.g. Guan et al., 2012; Zhang \& Chen, 2017; Lo et al., 2017; Guan et al., 2018) and phenological data (Guan, 2014). EMD-EEMD decomposes time series based on local behaviors and in a sequential manner, thus it does not assume either linearity or stationarity in data. The trend is derived intrinsically and adaptively, so it does not require an a priori structure (Wu et al., 2007). These properties make EEMD an ideal tool for separating TCs from the trend (Guan, 2014).

The decomposition was conducted using the Rlibeemd package (Helske \& Luukko, 2016) for R software. Each EEMD run comprised 5000 EMD runs. The standard deviation of the introduced Gaussian white noise was 0.1 of that of the average climatic and leaf litter production and composition series. For EEMD decomposition, each series was decomposed into a trendless component (the sum of the EEMD IMFs) and a trend. EEMDs of leaf litter variables were performed using averaged series at species and site level.

\section{Statistical analyses}

Between-sites and between-species differences in production of different litterfall fractions and nutrient concentrations and ratios, as well as identification of litterfall production peaks during the fall season were assessed with one-factor ANOVA. Linear mixed effects models (LMMs) were used to evaluate the effect of site or month (fixed factors) with plot nested in year as a random effect and a correlation structure to account for the repeated measures on the same plot. Differences between months were assessed with Tukey's post hoc comparisons.

Redundancy analyses (RDA) were performed to assess the influence of local climate and large-scale circulation indices on leaf litter dynamics from 2000 to 2017 based on experimental plots as cases. TC of leaf litter variables (biomass at monthly scale, and N:P:K concentrations and stoichiometry at annual scale) were considered as response matrices. Predictive matrix included SPEI, NAO and ENSO. Time scale (number of months considered for index calculation) and time lag (number of years prior to leaf abscission) of climate variables were selected following a stepwise procedure. We considered meaningful relationships with large-scale circulation indices as long as they were consistent with local climate variables. Lagged associations between pine needle litter composition and climate 
were assessed from lags zero to 48 months. Variance partitioning was used to estimate the variance explained by local climate and large-scale patterns, as well as the covariance between them (Brocard et al., 1992; Peres-Neto et al., 2006). We then performed spatiotemporal correlations of local climate and leaf litter variables with two detrended monthly gridded fields: HadISST1 dataset (a reconstructed $1^{\circ} \times 1^{\circ}$ sea surface temperature (SST) field; Rayner et al., 2003), and NCEP/NCAR dataset (a reanalysis of $2.5^{\circ} \times 2.5^{\circ}$ sea level pressure (SLP) field; Kalnay et al., 1996).

The relationships between leaf litter dynamics, water use and Scots pine tree growth were evaluated by means of principal component analysis (PCA) based on yearly data of experimental plots as cases and considering the effect of the factor 'Year'. All variables were standardized in order to avoid biases due to magnitude differences. First, the relationship between monthly pine needle litter production with TRW and iWUE of the same year was assessed. Second, the relationship among leaf litter quality and pine TRW and iWUE was analyzed considering the joint contribution of both species to leaf litter. For each species, concentration of nutrients was multiplied by the annual leaf litter biomass and then the nutrient content of both species was added. Time lags between leaf litter fall and TRW and iWUE (i.e. delay in years from leaf abscission to maximum effect on tree-ring formation) was assessed using LMMs, considering up to 5-year lagged leaf litter shedding. Models included nutrient content, stoichiometric relationships and site as fixed factors, as well as a random intersection associated with plot nested in year (random factor) and a first-order autocorrelation structure.

Finally, we applied a structural equation model (SEM) (Shipley, 2016) to unravel the simultaneous indirect and direct effects of large-scale circulation patterns (NAO and ENSO), and local climate (SPEI) on leaf litter dynamics and Scots pine TRW and iWUE. Causal relationships were based on simultaneous LMMs, which included EEMD detrended variables (i.e. TCs) as fixed factors and a random term with the form of plot nested in site. Goodness of fit was assessed with a $\chi^{2}$-test on the Fisher's $C$ statistic (Lefcheck, 2016).

LMMs and post hoc comparisons were carried out using the nlme (Pinheiro et al., 2017) and multcomp (Hothorn et al., 2008) packages for R software, respectively. Likewise, RDA and PCA analyses were conducted with the vegan package (Oksanen et al., 2017). Crosscorrelations and spatiotemporal correlations were conducted via the Royal Netherlands Meteorological Institute Climate Explorer website (http://climexp.knmi.nl/) (Trouet \& Van 
Oldenborgh, 2013). SEM analysis were conducted in R using the piecewiseSEM package (Lefcheck, 2016).

\section{RESULTS}

\section{Litterfall production and composition varied with species, sites, and climatic conditions}

Scots pine needles, beech leaves and leaves from other broadleaf species at the Mediterranean site, and pine needles at the continental site, accounted for more than $70 \%$ of total litterfall at both sites (Table 3). Although no significant differences between sites were found in autumn pine needle production (ANOVA, $F=3.595, p=0.131)$, beech leaves $(F=$ $19.291, p=0.012)$, leaves of other broadleaf species $(F=8.879, p=0.041)$, pine branches $(F$ $=32.821, p=0.005)$ and miscellaneous $(F=7.837, p=0.048)$, masses were higher at the Mediterranean site. Leaf litter dynamics were observed to shift from pine dominated to pine/beech co-dominated canopy at the Mediterranean site in 2016, whereas pine remained dominant in the continental canopy during the whole study (Fig. 1A).

Leaf litter production varied significantly during autumn (Table 3). Pine needle fall displayed a maximum in August-September at the Mediterranean site. However, the peak was delayed to September-October at the continental site. Meanwhile, massive beech leaf abscission was later than pine needles' peaks: November at the Mediterranean site and October at the continental site. A decreasing trend of needle litter production during early autumn months and a striking increase of beech leaves in November were observed at the Mediterranean site during the 18-year period (Fig. 1B). Beech leaf litter production was of lesser magnitude at the continental site (Fig. 1C).

All nutrient concentrations were significantly higher in beech leaves than in pine needles ([N]: $F=42.91, p=0.001 ;[\mathrm{P}]: F=10.78, p=0.022 ;[\mathrm{K}]: F=26.36, p=0.004)$. Between-site differences in leaf litter nutrient concentration varied depending on nutrient and species (Table 4). Significant differences $(p<0.05)$ between sites were found for $[\mathrm{P}]$ (MED site < CONT site) in pine needle litter, and for [N] (MED site > CONT site) and [K] (MED site > CONT site) in beech leaf litter (Table 4). N:P ratio of leaf litter was greater at the Mediterranean site, while the opposite pattern was found for P:K ratio (Table 4). Overall, N:P 
ratios showed a rising trend (Fig. 2D), while P:K ratios displayed a general decrease (Fig. 2F). No clear trends were found for N:K ratios (Fig. 2E).

Summer SPEI was negatively related with the timing of maximum pine needle litter production (September at the Mediterranean site and October at the continental site; Figs. 3A and 3B). That is, the higher the soil moisture during summer the later the needles fell. Beech leaf litter fallen in September was positively related with SPEI.1 september $_{\text {at }}$ both sites (Figs. 3C and 3D). Leaf litter $[\mathrm{N}]$ and $[\mathrm{P}]$ of both species showed positive relationships with late spring and summer water availability; in the case of pine the relationship was with SPEI of three years prior needle abscission (Fig. 4). Stoichiometric relationships of both species at the two sites responded homogeneously to water availability. Dry conditions in late spring and summer increased $\mathrm{N}: \mathrm{P}$ but reduced $\mathrm{N}: \mathrm{K}$ and $\mathrm{P}: \mathrm{K}$ ratios.

\section{Teleconnections of leaf litter dynamics}

Local climatic variables showed significant teleconnections with the North Atlantic and Pacific oceans. Results are detailed in the Supporting Information. In summary, previous winter NAO exerted a negative influence on late spring and early summer precipitation, while the influence of ENSO on precipitation was stronger during summer. Mean temperature was correlated with NAO in February and March and with ENSO during autumn.

The amount of variance of leaf litter dynamics explained by large-scale circulation patterns is larger than that explained by SPEI for both species at the Mediterranean site, and similar for pine needle litter at the continental site. Local climate accounted for larger variations of beech leaf litter dynamics at the continental site than large-scale climatic indices (Figs. 3 and 4). Early pine needle fall showed a positive relationship with NAO's positive phases during spring (Figs. 3A and 3B), whereas summer ENSO was positively related with October needle litter production at the Mediterranean site. For beech leaf litter, spring NAO was negatively correlated with leaf litter production in August and September, while October leaf litter production responded more to $\mathrm{ENSO}_{\text {September }}($ Figs. 3C and 3D). These patterns were reflected on the correlations found between leaf litter production and North Atlantic Ocean SLP and tropical Pacific Ocean SST for the period 2000 - 2017 (Fig. 5).

Three-year lagged winter NAO was negatively related to pine needle litter $[\mathrm{N}]$ and $[\mathrm{P}]$, while 3-year lagged spring ENSO had a negative influence on the N:P ratio (Figs. 4A and 4B). Beech leaf litter N:P ratio was positively affected by spring NAO and early summer 
ENSO (Figs. 4C and 4D). As in the case of leaf litter biomass, strong spatiotemporal correlations for the period 2000 - 2017 were found between leaf litter stoichiometric relationships and North Atlantic Ocean SLP and tropical Pacific Ocean SST (Fig. 6).

\section{Linking leaf litter dynamics, TRW and iWUE of Scots pine}

Figure 7A shows the relationship between timing of needle litter drop and tree-ring formation during the same year for Scots pine trees. PC1 explained $26.77 \%$ of variance and established a connection between needles fallen in September and TRW, which was also reduced as trees become older. PC2 related August needle litter and iWUE, and explained $20.63 \%$ of data set variability. The higher the iWUE, the earlier the needle abscission.

Composition and stoichiometry of 3-year lagged leaf litter explained the greatest variability of both TRW and iWUE (results not shown). PC1, which explained $34.71 \%$ of variance, encompasses most of the variability of Scots pine secondary growth. This axis established a relationship among $\mathrm{N}$ content, N:P and P:K ratios, TRW and year (Fig. 7B). The higher the $\mathrm{N}$ content and N:P ratio the lower the TRW, whereas the TRW-P:K ratio relationship was positive. PC2, which explained $20.3 \%$ of variance, related $\mathrm{P}$ content and $\mathrm{N}: \mathrm{K}$ ratio with iWUE. iWUE responded positively to $\mathrm{P}$ content of leaf litter, and negatively to $\mathrm{N}: \mathrm{K}$ ratio (Fig. 7B).

Additionally, we evaluated the hypothesis that coupled NAO and ENSO indirectly affect leaf litter dynamics through the influence on SPEI.3 $3_{\text {August }}$ (as a surrogate of summer water availability), and the effect of leaf litter dynamics on TRW and iWUE of Scots pine using SEM. The entire structured model resulted in an adequate goodness of fit based on Fisher's C statistic of $\mathrm{C}_{(\mathrm{df}=24)}=21.37(p=0.617)$. Our results show how NAO and ENSO indirectly affected leaf litter dynamics through the modification of summer SPEI (standardized coefficients -0.16 and 0.33 , respectively), which in turn had a noticeable direct effect on August pine needle litter production (standardized coefficient $=-0.24$ ), N:P and N:K ratios calculated as the weighted contribution of both Scots pine and beech (standardized coefficients -0.21 and 0.26 , respectively) (Fig. 8). NAO also showed a direct effect on $\mathrm{N}: \mathrm{K}$ ratio (standardized coefficient $=-0.22$ ). Seasonality of needle litter production showed stronger influence on iWUE (standardized coefficient $=0.21$ ) than on TRW (standardized coefficients $=-0.06$ ). Significant effect of 3-year lagged N:P ratio of weighted pine and beech on Scots pine TRW (standardized coefficient $=-0.22$ ), and a weaker effect of 3-year lagged weighted $\mathrm{N}: \mathrm{K}$ ratio on iWUE (standardized coefficient $=-0.12$ ). SEM analysis also disclosed 
a negative impact of iWUE on TRW of Scots pine (standardized coefficient $=-0.09$ ). The model was able to explain 30 and $34 \%$ of iWUE and TRW variances.

\section{DISCUSSION}

Litterfall is the largest natural inflow of organic material and nutrients to forest soils (Vitousek, 1982). Tree species occupying the same site can differ conspicuously in nutrient return through litterfall (Reich et al., 2005). In mixed-species forests, litter effects on soil properties depend on the tree species involved and their relative contribution to the litter pool (Staelens et al., 2011), but direct extrapolations from monospecific forests could not be accurate. Our first hypothesis was supported as a negative relationship was found between leaf litter N:P ratio and pine growth, suggesting P limitation of ecosystem processes such as decomposition. Our second hypothesis was also confirmed, as large-scale circulation patterns had a clear impact on leaf litter dynamics by modulating ecosystem water availability. Indeed, large-scale climatic indices accounted for greater variations in leaf litter dynamics than local climate.

\section{Influences of climate, site, and canopy composition on leaf litter production}

Leaves were the biggest fraction of aboveground litterfall, representing more than $70 \%$ and $80 \%$ of total litter mass at the Mediterranean and continental sites, respectively (Table 3). Consistently, leaf litter has been shown to be the most important litterfall fraction and the major determinant of nutrient cycling in forest communities owing to the high nutrient concentrations in leaves (Prescott, 2002). These percentages were similar to those found in several mixed forests (Wang et al., 2008; Staelens et al., 2011). Blanco et al. (2006) collected litterfall every month during two and a half years at the same experimental plots, showing that Scots pine needle litter production rates (Mediterranean site: $c a .3000 \mathrm{~kg} \mathrm{ha}^{-1} \mathrm{yr}^{-1}$; Continental site: $c a .2800 \mathrm{~kg} \mathrm{ha}^{-1} \mathrm{yr}^{-1}$ ) were in the upper edge of the range observed in Spain and more northern locations (Pausas, 1997; Santa Regina \& Tarazona, 2001; Martínez-Alonso et al., 2007; Starr et al., 2005).

The observed pine needle fall reduction at the Mediterranean site through the study period can be attributed to the increasing contribution of beech to total leaf litter (Fig. 1A). This increase is related to the expansion of beech crown cover in the plots during the last years, continuing the trend reported by Primicia et al. (2013) at the same site. At the 
Mediterranean site, the replacement of pine trees by beech trees following the patterns of natural succession is progressively occurring, and beech already exceeded pine in litter circulation by the end of the study period (2017). However, at the continental site the small magnitude of beech leaf litter highlighted that the successional process towards a mixed canopy is still in a preliminary stage at this site.

Climatic influence on litterfall dynamics could account for the seasonal variability of leaf fall within and between sites (Fig. 8). We have found distinct climatic effects on pine and beech, as reported by Liu et al. (2004) for coniferous and broadleaf forests at Eurasian scale. On one hand, pine needle fall responded to summer soil water conditions, so that the drier the summer the earlier the needle shedding (Figs. 3A and 3B). Water stress prevents the tree from maintaining all its leaf biomass and accelerates the fall of the older needles (Reich \& Borchert, 1984; Wright \& Cornejo, 1990; Pausas, 1997; Santa Regina \& Tarazona, 2001; Martínez-Alonso et al., 2007) because of an increase of abscisic acid levels (Sundarapandian \& Swamy, 1999). Several authors have reported this dependence between water availability and litterfall for pine species in mesic sites where drought periods are frequent (Pausas et al., 1994; Pausas, 1997; Berg \& Meentemeyer, 2001; Blanco et al., 2006; Martínez-Alonso et al., 2007), although other studies have found opposite results when there was no water limitation (Starr et al., 2005; Lehtonen et al., 2008). The role of temperature may be considered for interpreting such relationships as in the former case increased temperature may exacerbate water stress so hastening needle shedding, while in the latter warmer conditions could increase resource use for maintenance respiration. Such interactive effects of moisture conditions and temperature variations have been already described also in tropical and boreal ecosystems (e.g. Wang et al., 2014a; Reich et al., 2018). Consistently, the earlier needle fall peak at the Mediterranean site (August-September) compared to the continental site (September-October) was probably the result of greater water stress and higher temperatures during the summer period in the former site. On the other hand, abscission of beech leaves before the main peak because of high water availability in September (Figs. 3C and 3D) may seem contradictory according to the afore-mentioned explanation. However, it should be understood in terms of the physical impact exerted by precipitation, which can remove old and senescent leaves from the canopy. Consistently, frequent heavy rains and storm activity during autumn after the end of dry season have been reported in the Mediterranean region (Romero et al., 1998) where an increase in heavy precipitation events is expected (IPCC, 2013). 


\section{Leaf litter elemental composition: a proxy of ecosystem nutrient limitation}

Leaf litter nutrient status is primarily the product of the nutrient status of green leaves and the ratio of nutrient resorption (Killingbeck, 1996; Kobe et al., 2005). Nutrient concentrations in green leaves vary widely among different species, and such differences increase with phylogenetic distance (Sardans et al., 2015). Analogous differences in senescent leaves have been found when different functional groups were compared (e.g. coniferous vs. broadleaf; Kavvadias et al., 2001; Cornwell et al., 2008). Likewise, we have found outstanding differences between Scots pine and European beech, as concentrations of all macronutrients analyzed (N, P and $\mathrm{K})$ were higher in beech leaf litter than in pine needles (Fig. 2).

Besides between-species differences, nutrient composition and stoichiometry significantly differed between the two study sites (Table 4), suggesting the existence of other factors affecting leaf litter composition. Earlier studies have shown that both green leaves nutrients (e.g. Reich \& Oleksyn, 2004; Sardans et al., 2013) and its resorption in trees (e.g. Aerts, 1996; Killingbeck, 1996; Blanco et al., 2009; Primicia et al., 2014) are related to climatic factors. Therefore, leaf litter nutrients are expected to be partially climate-dependent. Indeed, global patterns of leaf litter nutrient variation at regional (Aerts, 2007; Liu et al., 2006) and global scales (Aerts, 1997; McGroddy et al., 2004; Yuan \& Chen, 2009; Kang et al., 2010) have been identified. Although those studies suggest that globally temperature is the most important climatic factor controlling leaf litter composition, in water-limited ecosystems, such as the Mediterranean ones, water availability may play a key role (e.g. García-Palacios et al., 2016). Accordingly, we have found that SPEI accounted for part of the year-to-year variability (Fig. 4). The observed maximum cross-correlations between SPEI and nutrient composition obtained with a long-term lag (three years) for pine could indicate that senescent needle composition is related to climate at the time of needle production as needles in the study stands have 3-5 years life span (Blanco et al., 2009; Primicia et al., 2014).

Water availability showed a positive relationship with $[\mathrm{N}]$ and $[\mathrm{P}]$ for both species. Drought may decrease nutrient mineralization (Cornwell et al., 2008; Zhang et al., 2008) and nutrient mobilization from the soil (Sardans \& Peñuelas, 2007; Yuan \& Chen, 2015a), which can reduce nutrient uptake and allocation to leaves (Sardans et al., 2012a; Sardans et al., 2012b; Kreuzwieser \& Gessler, 2010). Water availability has also been reported to modify nutrient resorption efficiencies (Del Arco et al., 1991, Yuan \& Chen, 2009b). However, our 
data set based on leaf litter nutrients does not allow us to disentangle the relative importance of each of those processes. N:P ratios responded negatively to water availability (Fig. 8). The $\mathrm{N}: \mathrm{P}$ ratio response to drought agrees with previous results from green leaves (Sardans et al., 2011; Sardans et al., 2013). Furthermore, the N:P ratios in senescent pine needles higher than those in green needles (see studies based on the same research forests: Blanco et al., 2009, and Primicia et al., 2014) indicated than pine trees resorb more $\mathrm{P}$ than $\mathrm{N}$ during senescence, as it is predicted to occur in P-limited ecosystems (McGroddy et al., 2004). Such results are also supported by our own previous studies at the same sites, which detected more intense $\mathrm{N}$ resorption at the Mediterranean site but more intense $\mathrm{P}$ resorption at the continental site (Table 4, Blanco et al., 2009). In any case, climate effects are difficult to isolate from the influence of soil fertility and other site-specific factors on green leaves composition and resorption.

Meanwhile, beech leaf litter [K] was negatively related to SPEI. K represents a particular case as it is highly mobile and can be increasingly leached away with higher rainfall, which agrees with the lower $[\mathrm{K}]$ in leaf litter from the continental site (Table 4, Fig. 2C). In addition, Primicia (2012) also reported higher [K] in througfall in autumn at the Mediterranean site. Furthermore, $\mathrm{K}$ is particularly important in dry environments since this element plays a role in controlling leaf water loss as it boosts stomatal function (Khosravifar et al., 2008), controls osmosis (Babita et al., 2010), and it is related to hydraulic conductance (Oddo et al., 2011). In summer, $\mathrm{K}$ is allocated to leaves in order to avoid water stress (Sardans et al., 2012a). This allocation could be reflected in leaf litter composition, a fact supported by the negative relationship between [K] and summer SPEI (Figs. 4C and 4D). SPEI was also associated with N:K and P:K ratios for both species (Figs. 4 and 8). Likewise, Gotelli et al. (2008) have reported that $\mathrm{N}: \mathrm{K}$ concentration ratios in plants correlate with the water content of soils.

Nutrient concentrations and their stoichiometric relationships in leaf litter can determine the rate of decomposition and nutrient release, and therefore their subsequent availability for other plants and soil organisms (Berg \& McClaugherty, 2003; Mooshammer et al., 2012). Hence, leaf litter nutrient status may inform about nutrient limitation at ecosystem level (Reed et al., 2012; Lang et al., 2016). The identification of critical leaf litter elemental stoichiometry ratios from which microbial decomposition is limited by $\mathrm{N}$ or $\mathrm{P}$ has been attempted in several studies (Aerts, 1997; Smith, 2002; Güsewell \& Freeman, 2005; Mooshammer et al., 2012). Güsewell (2004) and Güsewell \& Freeman (2005) found that decomposition was always Plimited for litter with N:P ratios above 20-22. Considering such threshold we could state that 
decomposition of leaf litter of both Scots pine and European beech is limited by $\mathrm{P}$ at the Mediterranean site (Fig. 2D). Beech litter N:P was in the 20-22 ratio during most of the research period at the continental site and previous studies at the same sites have reported that $\mathrm{P}$ is immobilized for at least 5 years, while some net mineralization of $\mathrm{N}$ occurred during that period (Blanco et al., 2011), suggesting than $\mathrm{P}$ could also be limiting decomposition rate.

Regardless of specific values, decomposition rates have been negatively associated with $\mathrm{N}: \mathrm{P}$ ratios of leaf litter (Schneider et al., 2012). Hence, the initial increasing patterns of N:P ratios of both species at both sites reached a peak in 2009-2013, remaining flat or decreasing afterwards. This temporal change broadly matches the radial growth rates observed for these species at both sites (González de Andrés et al., 2018; Candel-Pérez et al., 2018), and therefore it could indicate the end of the fast-growing juvenile stage of trees and the transition towards mature individuals (set in $\sim 50$ years for $P$. sylvestris in the Iberian Peninsula; Montero et al., 2001). In addition, our results for $\mathrm{N}: \mathrm{P}$ ratios also support the growth rate hypothesis, as the higher ratios were found for the site with better conditions for anabolic metabolism and during the years with the highest growth rates (Candel-Pérez et al., 2018), and therefore nutrients were more thoroughly reabsorbed prior to abscission (Rivas-Ubach $e t$ al., 2012). Consequently, such change could also result in slowing down the $\mathrm{P}$ mineralization rate, thus reducing $\mathrm{P}$ availability for trees.

P immobilization by soil microbes has been observed in P-depleted soils, where belowground microbial biomass contains the major proportion of P-pools (Vincent et al., 2013). Consistently, Blanco et al. $(2009,2011)$ and Primicia et al. (2014) have already proposed that the studied forests may be P-limited based on foliar nutrition, resorption, and decomposition information. Furthermore, $\mathrm{P}$ available in the upper mineral soil $\left(0.02 \mathrm{mg} \mathrm{g}^{-1}\right.$, see Table 2) at our sites appears to be relatively low compared with averages for coniferous $\left(0.84 \mathrm{mg} \mathrm{g}^{-1}\right)$ or deciduous $\left(0.98 \mathrm{mg} \mathrm{g}^{-1}\right)$ temperate forests (Sohrt et al., 2017). This situation could lead to a deterioration of $\mathrm{P}$ nutrition, as has been reported for Central European forests of Scots pine (Prietzel et al., 2008; Jonard et al., 2015) and European beech (Braun et al., 2010; Jonard et al., 2015; Talkner et al., 2015; Hofmann et al., 2016). Increases in P limitation and deterioration of tree $\mathrm{P}$ nutrition have been mainly attributed to high rates of $\mathrm{N}$ inputs to forest ecosystems (Peñuelas et al., 2013; Schmitz et al., 2019). The global pattern of increasing $\mathrm{N}$ deposition (Galloway et al., 2004) has been also reported for the last decades in NE Spain (Ávila \& Rodá 2012). Indeed, Pyrenean forests have been identified as one of the ecosystems with a higher saturation risk due to $\mathrm{N}$ deposition (García-Gómez et al., 2014). 
Accordingly, a situation close to $\mathrm{N}$ saturation in pine-beech mixtures of the Pyrenees has been proposed using a modeling approach (Blanco et al., 2017). The arise of a co-limitation by $\mathrm{N}$ and $\mathrm{P}$ in Pyrenean pine-beech mixtures could result in a higher sensitivity to other environmental stresses such as droughts or pests, which may prompt a rise in tree mortality (Braun et al., 2010; Blanco et al., 2012). This situation highlights the importance of understanding the links of nutrient circulation with climate oscillations (see next section).

Furthermore, nutrient mineralization is often limited by low $\mathrm{C}$ quality as a significant fraction of essential nutrients is bound to recalcitrant lignin-related compounds (ZechmeisterBoltenstern et al., 2015). The increasing contribution of European beech to forest leaf litter leading to the development of mixed stands over the last decades (Fig. 1A), particularly at the Mediterranean site, has major implications for turnover rates and nutrient cycling in the ecosystem. Deciduous leaf litter generally has lower lignin and polyphenol concentrations than conifer litter, so it would be expected to decompose faster (Perry et al., 1987) and even hasten the decomposition of needle litter (Polyakova \& Billor, 2007). In addition, beech leaf litter N:P ratios may reach lower values than those of pine needle litter (Fig. 2D). Niinemets \& Tamm (2005) stated that mixed-species forest communities appear to produce litters with chemical composition varying more widely than pure stands, and hence mixed litters might support a more diverse soil microfaunal and microbial populations.

\section{Connections among leaf litter dynamics and Scots pine radial growth and iWUE}

Although researchers have tried to connect leaf litter production with tree growth, results remain inconclusive. Different studies failed to detect such relationship from short litterfall series (Wirth et al., 2002; Martínez-Alonso et al., 2007). A weak correlation between productivity and litterfall was reported by Lehtonen et al. (2008) from a long-term study (43 years) in a Scots pine forest in Finland. However, in this study we have found that timing of Scots pine needle shedding influenced TRW, in such a way that the more needles fell in September, the more pine trees grew (Fig. 7A). Needle shedding prior to September was linked with water stress during summer, which has also been frequently associated with growth reductions in Mediterranean Scots pine populations (e.g. Martínez-Vilalta et al., 2008; Primicia et al., 2013; Marqués et al., 2017). Indeed, warming-induced drought at the beginning of the growing season has been identified as the major constraint on growth of Mediterranean Scots pine populations (Sánchez-Salguero et al., 2015). Both Primicia et al. (2013) and Cardil et al. (2018) have reported a secondary growth peak of Scots pine in 
October at these sites for which the maintenance of green needles longer in autumn may play a key role. Accordingly, the interaction between precipitation and temperature during autumn has been found to be an important climatic growth driver for the studied pine stands (González de Andrés et al., 2018). Further, seasonality of needle litter production was linked with pine iWUE through the effect of water availability (Fig. 8). The effect of air humidity or soil moisture on tree ring iWUE has been widely reported (e.g. Waterhouse et al., 2004; Linares \& Camarero, 2012; González de Andrés et al., 2018). Summer water stress could produce premature needle shedding in August, which finally resulted in formation of treerings with greater iWUE (Fig. 7A). In addition, if summer drought is severe enough, it could cause enhanced leaf senescence and reduced leaf production for several years after (Corcuera et al. 2004). However, such legacy effect was not found in litter dynamics at our sites (see Table S1 in Supporting Information). Similarly, we have recorded ring width and wood density reductions in years of intense summer droughts, but tree growth quickly recovered the following years without generating noticeable legacy effects (Candel-Pérez et al. 2018).

Forests productivity and litter quality are highly dependent on soil nutrient availability, which is determined in part by leaf litter composition and stoichiometry. Therefore, rates of decomposition and mineralization are strongly influenced by litter quality. Following the consumer-driven nutrient recycling theory (Sterner \& Elser 2002), we assumed that leaf litter stoichiometry influences the rate at which each nutrient becomes available for tree uptake. Supporting this assumption, we have found a negative relationship between TRW and N:P ratio of leaf litter fallen three years prior to tree-ring formation (Fig. 7B), a fact that is also in concordance with the P-limited decomposition previously reported (see section 4.2.). This result should be cautiously interpreted as net $\mathrm{P}$ release has not been observed at these sites after three years of decomposition neither for pine needles (Blanco et al., 2011) nor for beech leaves (unpublished results). Instead, high N:P ratios may negatively affect growth rate of soil microbes (as stated by the growth rate hypothesis, Sterner \& Elser, 2002), and thus reduce the rate of leaf litter decomposition (Fig. 8).

Scots pine iWUE also responded to stoichiometry of leaf litter fallen with a 3-year time lag, showing a negative relationship with $\mathrm{N}: \mathrm{K}$ ratios (Fig. 7B). Recent studies have evidenced the important role of $\mathrm{K}$ content and its stoichiometric relationships for water stress resistance in the Mediterranean region (Sardans \& Peñuelas, 2007; Sardans et al., 2012a; Sardans et al., 2013). Therefore, $\mathrm{K}$ is a key element in tree physiology involved in cellular osmosis 
adjustment, stomata control and water-use efficiency (Babita et al., 2010), and it needs to be included in stoichiometric studies.

\section{Large-scale circulation patterns impacts on leaf litter dynamics}

Leaf litter dynamics may not reflect only local climate variations, but also large-scale atmospheric-oceanic circulations, which can provide a broad understanding of observed changes in the local physical environment and the associated ecological processes (Stenseth $e t$ al., 2002; Stenseth et al., 2003; Hallet et al., 2004). In this study, the amount of variance in leaf litter dynamics explained by large-scale climatic indices was generally larger than the variance explained by local indices (Figs. 3 and 4). These associations can be understood through the afore-mentioned impact of water availability on litterfall, as atmospheric-oceanic circulations exert their influences on ecological systems through local weather variations (see a detailed discussion in Appendix B) (Stenseth et al., 2003).

Positive phases of NAO during winter and spring and negative phases of ENSO at summer may have caused drier conditions during the growing season (see Appendix $\mathrm{C}$ for a mechanistic explanation) (Fig. S5), hastening early needle shedding (Fig. 3). In the case of beech leaves, the impact of NAO may be explained by its teleconnection with wind conditions: positive phases of NAO are associated with a decrease in the number of extreme wind events in the western Mediterranean region (Nissen et al., 2010). Thus, advanced beech leaf shedding could be associated with storm activity during September (Figs. 3 and 5).

Our results suggest complex leaf litter dynamics regulated by global atmospheric-oceanic patterns, in which leaf litter seasonality and composition are simultaneously affected by global processes originated in both the North Atlantic and Pacific oceans (Figs. 5 and 6). The predicted changes of NAO towards more positive phases and the intensification of ENSOinduced rainfall variability due to changes in moisture availability (Christensen et al., 2013) may enhance the frequency and severity of droughts in the Pyrenees (IPCC, 2013). However, such predictions should be taken with caution as modelling studies of the behaviour of atmospheric circulation patterns under future climate are either contradictory (e.g. Davini \& Cagnazzo, 2014) or inconclusive (e.g. Maher et al., 2018). In any case, considering the correlation between water availability and leaf litter dynamics in Scots pine - European beech mixtures in their distribution edges, decreases in decomposition and nutrient release rates and trees nutrition deterioration might be expected. Hence, direct effects of water shortage would be worsened in drought-prone environments, such as circum-Mediterranean regions, by 
reducing the capacity of trees to use water efficiently and the consequent decrease in growth and carbon storage capacity.

\section{CONCLUSIONS}

Long-term studies of litterfall dynamics are important to reach a better understanding of energy and nutrients transfers from trees to soil in forest ecosystems. In the relatively short time of 18 years (referred to trees' life span), natural succession at these forests has progressed to a point in which European beech crown cover has expanded into formerly Scots pine-dominated stands, taken the lead as the main species in litterfall cycling. This change may have important effects on forest functioning, considering seasonal and compositional differences between leaf litters of both species.

Large-scale atmospheric-oceanic oscillations account for major variations in water availability in the Pyrenees. Water availability has been found to play an important role in leaf litter seasonality and quality of Pyrenean Scots pine-beech mixtures. Increasing trends of $\mathrm{N}: \mathrm{P}$ ratios in leaf litter of both species, particularly at the Mediterranean site, pointed out to increasing P limitation in those mixtures. Relationships between leaf litter seasonality, stoichiometry, stem growth and water-use efficiency of Scots pine were established.

Under the predicted reduction in summer precipitation between 3 to $23 \%$ and increasing summer temperatures by 1.2 to $2.3^{\circ} \mathrm{C}$, the current anthropic climate change will have an important impact on litterfall and nutrient dynamics in circum-Mediterranean regions. Our work provides a mechanistic evidence of the complex interconnections among global and local climatic drivers, leaf litter dynamics and Scots pine performance in terms of radial growth and water-use efficiency. It highlights the importance of understanding the potential cascading effects that modifications in global climate patterns have on site-level ecological processes in mixed forests.

\section{ACKNOWLEDGEMENTS}

This research was funded by the Spanish Ministry of Economy and Competitiveness (projects AGL2012-33465 and AGL2016-76463-P). E.G.A. was funded through a Spanish Predoctoral Research Grant (ref. BES-2013-066705). J.A.B. was funded through a Ramón y 
Cajal contract (ref. RYC-2011-08082) and a Marie Curie Action (ref. CIG-2012-326718ECOPYREN3). Y.H.L. was funded through a Marie Skłodowska-Curie Action (ref. EF-2014656810-DENDRONUTRIENT).The authors also want to thank the collaboration of all the undergraduate, graduate students and postdoctoral fellows that along these 19 years collaborated in the generation of one of the longest continuous series of litterfall production in Europe. Their names are listed in the supporting information. The authors declare not having any conflict of interests.

\section{REFERENCES}

Aerts R. (1996) Nutrient resorption from senescing leaves of perennials: are there general patterns? Journal of Ecology, 85, 597-608.

Aerts R. (1997) Climate, leaf litter chemistry and leaf litter decomposition in terrestrial ecosystems: A triangular relationship. Oikos, 79, 439- 449.

Aerts R., Chapin F.S. (2000) The mineral nutrition of wild plants revisited: a re-evaluation of processes and patterns. Advances in Ecological Research, 30, 1-67.

Ammer C. (2017) Unraveling the Importance of Inter-and Intraspecific Competition for the Adaptation of Forests to Climate Change. In: Cánovas, F., Lüttge, U., Matyssek, R. (Eds) Progress in Botany Vol. 78. Springer, Berlin, pp. 129-152.

Ávila A., Rodá F. (2012) Changes in atmospheric deposition and streamwater chemistry over 25 years in undisturbed catchments in a Mediterranean mountain environment. Science of the Total Environment, 434, 18-27.

Babita M., Maheswari M., Rao L.M., Shanker A.K., Rao D.G. (2010) Osmotic adjustment, drought tolerance and yield in castor (Ricinus communis L.) hybrids. Environmental and Experimental Botany, 69, 243-249.

Barbeito I., Dassot M., Bayer D., Collet C. (2017) Terrestrial laser scanning reveals differences in crown structure of Fagus sylvatica in mixed vs. pure European forests. Forest Ecology and Management, 405, 381-390.

Beguería S., Vicente-Serrano S.M. (2017) SPEI: Calculation of the Standardised Precipitation-Evapotranspiration Index. R package version 1.7. https://CRAN.Rproject.org/package $=$ SPEI

Berg B., Meentemeyer V. (2001) Litter fall in some European coniferous forests as dependent on climate: a synthesis. Canadian Journal of Forest Research, 31, 292-301. 
Berg B., McClaugherty C. 2003. Plant litter: decomposition, humus formation, carbon sequestration. Springer- Verlag, Berlin, Germany, pp. 338.

Blanco J.A., Imbert J.B., Castillo F.J. (2006) Influence of site characteristics and thinning intensity on litterfall production in two Pinus sylvestris L. forests in the western Pyrenees. Forest Ecology and Management, 237, 342-352.

Blanco J.A., Imbert J.B., Castillo F.J. (2008) Nutrient return via litterfall in two contrasting Pinus sylvestris forests in the Pyrenees under different thinning intensities. Forest Ecology and Management, 256, 1840-1852.

Blanco J.A., Imbert J.B., Castillo F.J. (2009) Thinning affects nutrient resorption and nutrientuse efficiency in two Pinus sylvestris stands in the Pyrenees. Ecological Applications, 19, 682-698.

Blanco J.A., Imbert J.B., Castillo F.J. (2011) Thinning affects Pinus sylvestris needle decomposition rates and chemistry differently depending on site conditions. Biogeochemistry, 106, 397-414.

Blanco J.A., Wei X., Jiang H., Jie C.Y., Xin Z.H. (2012) Enhanced nitrogen deposition in south-east China could partially offset negative effects of soil acidification on biomass production of Chinese fir plantations. Canadian Journal of Forest Research, 42, 437450.

Blanco J.A., San Emeterio L., González de Andrés E., Imbert J.B., Larrainzar E., Peralta J., Lo Y.H., Castillo F.J. (2017) ¿Están los bosques mixtos pirenaicos de pino silvestre y haya en el camino hacia la saturación por nitrógeno? Ecosistemas, 26, 66-78.

Borcard D., Legendre P., Drapeau P. (1992) Partialling out the spatial component of ecological variation. Ecology, 73, 1045-1055.

Braun S., Thomas V.F.D., Quiring R., Flückiger, W. (2010) Does nitrogen deposition increase forest production? The role of phosphorus. Environmental Pollution, 158, 2043-2052.

Calbó J., Sanchez-Lorenzo A., Barrera-Escoda A., Cunillera J. (2012) Climate change projections for Catalonia (NE Iberian Peninsula). Part II: Integrating several methodologies. Tethys, 9, 13-24.

Camarero J.J. (2011) Direct and indirect effects of the North Atlantic Oscillation on tree growth and forest decline in northeastern Spain. In: Vicente-Serrano, S.M. \& Trigo, M. (Eds.), Hydrological, Socioeconomic and Eco-logical Impacts of the North Atlantic Oscillation in the Mediterranean Region. (pp. 129-152). New York, USA, Springer. 
Candel-Pérez D., Lo Y.H., Blanco J.A., Chiu C.M., Camarero J.J., González de Andrés E., Imbert J.B., Castillo F.J. (2018). Drought-induces changes in Wood density are not prevented by thinning in Scots pine stands. Forests, 9, 4, doi:10.3390/f9010004.

Cardil A., Imbert J.B., Camarero J.J., Primicia I., Castillo F.J. (2018) Temporal interactions among throughfall, type of canopy and thinning drive radial growth in an Iberian mixed pine-beech forest. Agricultural and Forest Meteorology, 252, 62-74.

Castro-Díez Y., Pozo-Vázquez D., Rodrigo F.S., Esteban-Parra M.J. (2002) NAO and winter temperature variability in southern Europe. Geophysical Research Letters, 29, 1160.

Christensen J.H., Krishna Kumar K., Aldrian E., An S.-I., Cavalcanti I.F.A., de Castro M., Dong W., Goswami P., Hall A., et al. (2013) Climate phenomena and their relevance for future regional climate change. In: Stocker, T.F., Qin, D., Plattner, G.K., Tignor, M., Allen, S.K., Boschung, J., et al. (Eds.), Climate Change 2013: The physical science basis contribution of working group I to the fifth assessment report of the Intergovernmental Panel on Climate Change. (pp. 1217-1308). New York, Cambridge University Press.

Corcuera L., Camarero J.J., Gilpelegrin E. (2004). Effects of a severe drought on Quercus ilex radial growth and xylem anatomy. Trees, 18, 83-92.

Cornwell W.K., Cornelissen J.H.C., Amatangelo K., Dorrepaal E., Eviner V.T., Godoy O., et al. (2008) Plant species traits are the predominant control on litter decomposition rates within biomes worldwide. Ecology Letters, 11, 1065-1071.

Davini P., Cagnazzo C. (2014) On the misinterpretation of the North Atlantic Oscillation in CMIP5 models. Climate Dynamics, 43, 1497-1511.

Del Arco J.M., Escudero A., Garrido M.V. (1991) Effects of site characteristics on nitrogen retranslocation from senescing leaves. Ecology 72(2):701-708.

Del Río M., Pretzsch H., Ruíz-Peinado R., Ampoorter E., Annighöfer P. et al. (2017) Species interactions increase the temporal stability of community productivity in Pinus sylvestris-Fagus sylvatica mixtures across Europe. Journal of Ecology, 105, 10321043.

Duffy J.E., Godwin C.M., Cardinale B.J. (2017) Biodiversity effects in the wild are common and as strong as key drivers of productivity. Nature, 549, 261-264.

Escudero A., Del Arco J.M., Sanz I.C., Ayala J. (1992) Effects of leaf longevity and retranslocation efficiency on the retention time of nutrients in the leaf biomass of different woody species. Oecologia, 90, 80-87. 
Fernández J., Casanueva A., Montávez J.P., Gaertner M.A., Casado Calle M.J., Manzanas R., Gutiérrez Llorente J.M. (2017) Regional climate projections over Spain: atmosphere. Future climate projections. CLIVAR Exchanges, 73, 45-52.

Farquhar G.D., O’Leary H.M., Berry J.A. (1982). On the relationship between carbon isotope discrimination and the intercellular carbon dioxide concentration in leaves. Australian Journal of Plant Physiology, 9, 121-137.

Fritts H.C. (2001) Tree rings and climate. Caldwell, NJ: Blackburn Press.

Galloway J.N., Dentener F.J., Capone D.G. et al. (2004) Nitrogen cycles: past, present, and future. Biogeochemistry, 70, 153-226.

Gamfeldt L., Snäll T., Bagchi R., Jonsson M., Gustafsson L., Kjellander P., Ruiz-Jaen M.C., Fröberg M., Stendahl J., Philipson C.D., et al. (2013). Higher levels of multiple ecosystem services are found in forests with more tree species. Nature Communications, 4, 1340 .

Gámiz-Fortis S.R., Hidalgo-Muñoz J.M., Argüeso D., Esteban-Parra M.J., Castro-Díez Y. (2011) Spatio-temporal variability in Ebro river basin (NE Spain): Global SST as potential source of predictability on decadal time scales. Journal of Hydrology, 409, 759-775.

García-Gómez H., Garrido J.L., Vivanco M.G., Lassaletta L., Rábago I.I., Ávila A., Tsyro S., Sánchez G., González Ortiz A., González Fernández I., Alonso R. (2014) Nitrogen deposition in Spain: modeled patterns and threatened habitats within the Natura 2000 network. Science of the Total Environment, 485-486, 450-460.

García-Palacios P., Maestre F.T., Kattge J., Wall, D.H. (2013) Climate and litter quality differently modulate de the effect of soil fauna on litter decomposition across biomes. Ecological Letters, 16, 1045-1053.

García-Palacios P., Prieto I., Ourcival J.M., Hättenschwiler S. (2016) Disentangling the litter quality and soil microbial contribution to leaf and fine root litter decomposition responses to reduced rainfall. Ecosystems, 19, 490-503.

González de Andrés E., Seely B., Blanco J. A., Imbert J. B., Lo Y.H., Castillo F. J. (2017) Increased complementarity in water-limited environments in Scots pine and European beech mixtures under climate change. Ecohydrology, 10, e1810.

González de Andrés E., Camarero J.J., Blanco J.A., Imbert J.B., Lo Y.H., Sangüesa-Barreda G., Castillo F.J. (2018) Tree-to-tree competition in mixed European beech-Scots pine forests has different impacts on growth and water-use efficiency depending on site conditions. Journal of Ecology, 106, 59-75. 
Gotelli N.J., Mouser P.J., Hudman S.P., Morales S.E., Ross D.S., Ellison A.M. (2008)

Geographic variation in nutrient availability, stoichiometry, and metal concentrations of plants and pore-water in ombrotrophic bogs in New England, USA. Wetlands, 28, 837840.

Guan B.T, Wright W.E., Chung C.H., Chang S.T. (2012) ENSO and PDO strongly influence Taiwan spruce height growth. Forest Ecology and Management, 267, 50-57.

Guan B.T. (2014) Ensemble empirical mode decomposition for analyzing phenological responses to warming. Agricultural and Forest Meteorology, 194, 1-7.

Guan B.T., Wright W.E., Cook E.R. (2018). Ensemble empirical mode decomposition as an alternative for tree-ring chronology development. Tree-ring Research, 74, 1-11.

Güsewell S. (2004) N:P ratios in terrestrial plants: variation and functional significance. New Phytologist, 164, 243-266.

Güsewell S., Freeman C. (2005) Nutrient limitation and enzyme activities during litter decomposition of nine wetland species in relation to litter N:P ratios. Functional Ecology, 19, 582-593.

Güsewell S., Bailey K.M., Roem W.J., Bedford B.L. (2005) Nutrient limitation and botanical diversity in wetlands: can fertilisation raise species richness? Oikos, 109, 71-80.

Güsewell S., Gessner M.O. (2009) N:P ratios influence litter decomposition and colonization by fungi and bacteria in microcosms. Functional Ecology, 23, 211-219.

Hallett T.B., Coulson T., Pilkington J.G., Clutton-Brock T.H. (2004) Why large-scale climate indices seem to predict ecological processes better than local weather. Nature, 430, 7175.

Helske J., Luukko P. (2017) Rlibeemd: Ensemble empirical mode decomposition (EEMD) and its complete variant (CEEMDAN)_. R package version 1.4.0, <URL: https://github.com/helske/Rlibeemd>

Hofmann K., Heuck C., Spohn M. (2016) Phosphorus resorption by young beech trees and soil phosphatase activity as dependent on phosphorus availability. Oecologia, 181, 369379.

Holmes R.L. (1983) Computer-assisted quality control in tree-ring dating and measurement. Tree-Ring Bulletin, 43, 69-78.

Hothorn T., Bretz F., Westfall P. (2008) Simultaneous inference in general parametric models. Biometrical Journal, 50, 346-363.

Huang N.E., Shen Z., Long S.R., Wu M.C., Shih H.H., Zheng Q., Yen N.C., Tung C.C., Liu H.H. (1998) The empirical mode decomposition and the Hilbert spectrum for nonlinear 
and non-stationary time series analysis. Proceedings of the Royal Society of London A, 454, 903-995.

Huang N.E., Wu Z. (2008) A review on Hilbert-Huang transform: Method and its applications to geophysical studies. Reviews of Geophysics, 46, 1-23.

Hurrell J.W. (1995) Decadal trends in the North Atlantic Oscillation: regional temperatures and precipitation. Science, 269, 676-679.

Hurrell J., Van Loon H. (1997) Decadal variations in climate associated with the North Atlantic Oscillation. Climlate Change, 36, 301-326.

IPCC (2013) Summary for policymakers. In: Stocker, T.F., Qin, D., Plattner, G.K., Tignor, M., Allen, S.K., Boschung, J., et al. (Eds.), Climate Change 2013: The physical science basis contribution of working group I to the fifth assessment report of the Intergovernmental Panel on Climate Change. (pp. 3-29). New York, Cambridge University Press.

Iriarte A., Puertas, F. (2003) Thinning experiment in a natural stand of Pinus sylvestris L., Aspurz (Navarre). Proceedings of the IUFRO meeting on Silviculture and sustainable management in mountain forests in the western Pyrenees. IUFRO, Navarre, Spain.

Jactel H., Bauhus J., Boberg J., Bonal D., Castagneyrol B., Gardiner B., Gonzalez-Olabarria J.R., Koricheva J., Meurisse N., Brockerhoff E.G. (2017) Tree diversity drives forest stand resistance to natural disturbances. Current Forestry Reports, 3, 223-243.

Joly F.X., Milcu A., Scherer-Lorenzen M., Jean L.K., Bussotti F., Dawud S.M., Müller S., Pollastrini M., Raulund-Rasmussen K., Vesterdal L., Hättenschwiler S. (2017) Tree species diversity affects decomposition through modified micro-environmental conditions across European forests. New Phytologist, 214, 1281-1293.

Jonard M., Fürst A., Verstraeten A., Thimonier A., Timmermann V., Potocic N. et al. (2015) Tree mineral nutrition is deteriorating in Europe. Global Change Biology, 21, 418-430. Kalnay E., Kanamitsu M., Kistler R., Collins W. et al. (1996) The NCEP/NCAR 40-Year Reanalysis Project. Bulletin of American Meteorological Society, 77, 437-471.

Kang H., Xin Z., Berg B., Burgess P.J., Liu Q., Liu Z., Li Z., Liu C. (2010) Global pattern of leaf litter nitrogen and phosphorus in woody plants. Annals of Forest Science, 67, 811.

Kavvadias V.A., Alifragis D., Tsiontsis A., Brofas G., Stamatelos. G. (2001) Litterfall, litter accumulation and litter decomposition rates in four forest ecosystems in northern Greece. Forest Ecology and Management, 144, 113-127. 
Khosravifar S., Yarnia M., Benam M.B.K., Moghbeli A.H.H. (2008) Effect of potassium on drought tolerance in potato cv. Journal of Food Agriculture and Environment, 6, 236241.

Killingbeck K.T., May J.D., Nyman S. (1990) Foliar senescence in an aspen (Populus tremuloides) clone: the response of element resorption to interramet variation and timing of abscission. Canadian Journal of Forest Research, 20, 1156-1164.

Killingbeck K.T. (1996) Nutrients in senesced leaves: keys to the search for potential resorption and resorption proficiency. Ecology, 77, 1716-1727.

Kobe R.K., Lepczyk C.A., Iyer M. (2005) Resorption efficiency decreases with increasing green leaf nutrients in a global data set. Ecology, 86, 2780-2792.

Kreuzwieser J., Gessler A. (2010) Global climate change and tree nutrition: influence of water availability. Tree Physiology, 30, 1221-1234.

Kuo S. (1996) Phosphorus. In: Sparks D.L. (Ed.) Methods of Soil Analysis: Part 3- Chemical and Microbiological Properties. (pp. 869-919), American Society of Agronomy, Madison, Wisconsin.

Lang F., Bauhus J., Frossard E., George E., Kaiser K., Kaupenjohann M., Krüger J., Matzner E., Polle A., Prietzel J., Rennenberg H., Wellbrock N. (2016) Phosphorus in forest ecosystems: New insights from an ecosystem nutrition perspective. Journal of Plant Nutrition and Soil Science, 179, 129-135.

Lefcheck J.S. (2016) piecewiseSEM: piecewise structural equation modelling in R for ecology, evolution, and systematics. Methods Ecology and Evolution, 7, 573-579.

Lehtonen A., Lindholm M., Hokkanen T., Salminen H., Jalkanen R. (2008) Testing the dependence between growth and needle litterafall in Socts pine - a case study in northern Finland. Tree Physiology, 28, 1741-1749.

Li P., Yang Y.S., Han W., Fang J. (2014) Global patterns of soil microbial nitrogen and phosphorus stoichiometry in forest ecosystems. Global Ecology and Biogeography, 23, 979-987.

Linares J.C., Camarero J.J. (2012) From pattern to process: Linking intrinsic water-use efficiency to drought-induced forest decline. Global Change Biology, 18, 1000-1015.

Liu C., Westman C.J., Berg B., Kutsch W., Wang G.Z., Man R., Ilvesniemii H. (2004) Variation in litterfall-climate relationships between coniferous and broadleaf forests in Eurasia. Global Ecology and Biogeography, 13, 105-114. 
Liu C., Berg B., Kutsch W., Westman C.J., Ilvesniemi H., Shen X., Shen G., Chen X. (2006) Leaf litter nitrogen concentration as related to climatic factors in Eurasian forests. Global Ecology and Biogeography, 15, 438-444.

Lo Y.H., Blanco J.A., Guan, B.T. (2017) Douglas-fir radial growth in interior British Columbia can be linked to long-term oscillations in Pacific and Atlantic sea surface temperatures. Canadian Journal of Forest Research, 47, 371-381.

Madrigal-González J., Ballesteros-Cánovas J.A., Herrero A., Ruiz-Benito P., Stoffel M., Lucas-Borja M.E., Andivia E., Sancho-García C., Zavala, M.A. (2018) Forest productivity in southwestern Europe is controlled by coupled North Atlantic and Atlantic Multidecadal Oscillations. Nature Communications, 8: 2222.

Maher N., Matei D., Milinski S., Marotzke J. (2018) ENSO change in climate projections: Forced response or internal variability? Geophysical Research Letters, 45, 1139011398.

Marqués L., Madrigal-González J., Zavala M.A., Camarero J.J., Hartig F. (2017) Last-century forest productivity in a managed dry-edge Scots pine population: the two sides of the climate warming. Ecological Applications, 0, 1-11.

Martínez-Alonso C., Valladares F., Camarero J.J., López Arias M., Serrano M., Rodríguez J.A. (2007) The uncoupling of secondary growth, cone and litter production by intradecadal climatic variability in a Mediterranean Scots pine forest. Forest Ecology and Management, 253, 19-29.

Martínez-Vilalta J., López, B.C. Adell, N. Badiella L., Ninyerola M. (2008) Twentieth century increase of Scots pine radial growth in NE Spain shows strong climate interactions. Global Change Biology, 14, 2868-2881.

Matejovic I. (1993) Determination of carbon, hydrogen, and nitrogen in soils by automated elemental analysis (dry combustion method). Communications in Soil Science and Plant Analysis, 24, 2213-2222.

McGroddy M.E., Daufresne T., Hedin L.O. (2004) Scaling of C:N:P stoichiometry in forests worldwide: implications of terrestrial redfield-type ratios. Ecology, 85, 2390-2401.

Metz J., Annighöfer P., Schall P., Zimmermann J., Kahl T., Schulze E. D., Ammer C. (2016). Site-adapted admixed tree species reduce drought susceptibility of mature European beech. Global Change Biology, 22, 903-920.

García Abejón J.L., Tella Ferreiro G. (1986) Tablas de producción de densidad variable para Pinus sylvestris L. en el Sistema Pirenaico. Comunicaciones INIA, Serie Recursos Naturales, 43, Madrid. 
Mooshammer M., Wanek W., Schnecker J., Wild B., Leitner S., Hofhansl F., Blöchl A., Hämmerle I., Frank A.H., Fuchslueger L., Keiblinger K.M., Zechmeister-Boltenstern S. Richter A. (2012) Stoichiometric controls of nitrogen and phosphorus cycling in decomposing beech leaf litter, Ecology, 93, 770-782.

Mooshammer M., Wanek W., Zechmeister-Boltenstern S., Richter A. (2014) Stoichiometric imbalances between terrestrial decomposer communities and their resources: mechanisms and implications of microbial adaptations to their resources. Frontiers in Microbiology, 5, 1-10.

Nickmans H., Collet C., Bonal D., Verheyen K., Ponette Q. (2017) Tree size and local neighbourhood affect foliar nutrient content in a mixed plantation of beech (Fagus sylvatica) and maple (Acer pseudoplatanus). Forest Ecology and Management, 400, 159-172.

Niinemets Ü., Tamm Ü. (2005) Species differences in timing of leaf fall and foliage chemistry modify nutrient resorption efficiency in deciduous temperate forest stands. Tree Physiology, 25, 1001-1014.

Nissen K.M., Leckebusch G.C., Pinto J.G., Renggli D., Ulbrich S., Ulbrich U. (2010) Cyclones causing wind storms in the Mediterranean: characteristics, trends and links to large-scale patterns. Natural Hazards and Earth System Sciences, 10, 1379-1391.

Oddo E., Inzerillo S., La Bella F., Grisafi F., Salleo S., Nardini A., Goldstein G. (2011) Shortterm effects of potassium fertilization on hydraulic conductance of Laurus nobilis L. Tree Physiology, 31, 131-138.

Oksanen J., Blanchet F.G., Friendly M., Kindt R., Legendre P., McGlinn D., Minchin P.R., O'Hara R.B., Simpson G.L., Solymos P., Stevens M.H.H., Szoecs E., Wagner H. (2017). vegan: Community Ecology Package. R package version 2.4-4.

Osborn T.J. (2011) Variability and changes in the North Atlantic Oscillation Index. In: Vicente-Serrano, S.M. \& Trigo, M. (Eds.), Hydrological, Socioeconomic and Ecological Impacts of the North Atlantic Oscillation in the Mediterranean Region. (pp. 922). New York, USA, Springer.

Parton W., Silver W.L., Bruke I.C., Grassens L., Harmon M.E., Currie W.S., King J.Y., Adair E.C., Brandt L.A., Hart S.C., Fasth, B. (2007) Global-scale similarities in nitrogen release patterns during long-term decomposition. Science, 315, 361-364.

Pausas J.G. (1997) Litter fall and litter decomposition in Pinus sylvestris forest of the eastern Pyrenees. Journal of Vegetation Science, 8, 643-650. 
Pausas J.G., Carceller F., Vallejo R. (1994) El desfronde en bosques de Pinus sylvestris L. en relación con las características climáticas. Ecología, 8, 167-176.

Peñuelas J., Poulter B., Sardans J., Ciais P. et al. (2013) Human-induced nitrogen-phosphorus imbalances alter natural and managed ecosystems across the globe. Nature Communications, 4, 2934.

Peres-Neto P., Legendre P., Dray S., Borcard D. (2006) Variation partitioning of species data matrices: estimation and comparison of fractions. Ecology, 87, 2614-2625.

Perry D.A., Choquette C., Schroeder P. (1987) Nitrogen dynamics in conifer-dominated forests with and without hardwoods. Canadian Journal of Forest Research, 17, 14341441 .

Pinheiro J., Bates D., DebRoy S., Sarkar D., R Core Team (2017) nlme: Linear and Nonlinear Mixed Effects Models_. R package version 3.1-131, <URL: https://CRAN.Rproject.org/package $=$ nlme>

Piovesan G., Schirone B. (2000) Winter North Atlantic Oscillation effects on the tree rings of the Italian beech (Fagus sylvatica L.). International Journal of Biometeorology, 44,121-127.

Polyakova O., Billor N. (2007) Impact of deciduous tree species on litterfall quality, decomposition rates and nutrient circulation in pine stands. Forest Ecology and Management, 253, 11-18.

Portillo-Estrada M., Korhonen J.F.J., Pihlatie M., Pumpanen J., Frumau A.K.F. Morillas L., Tosens T., Niinemets Ü. (2013) Inter- and intra-annual variations in canopy fine litterfall and carbon and nitrogen inputs to the forest floor in two European coniferous forests. Annals of Forest Science, 70, 367-379.

Post E., Stenseth N.C. (1999) Climatic variability, plant phenology, and northern ungulates. Ecology, 80, 1322-1339.

Pozo-Vázquez D., Gámiz-Fortis S.R., Tovar-Pescador J., Esteban-Parra M.J., Castro-Díez Y. (2005) El Niño-Southern Oscillation events and associated European winter precipitation anomalies. International Journal of Climatology, 25, 17-31.

Prescott C.E. (2002) The influence of the forest canopy on nutrient cycling. Tree Physiology, 22, 1193-1200.

Pretzsch H., Del Río M., Ammer C., Avdagic A., Barbeito I., Bielak K. et al. (2015). Growth and yield of mixed versus pure stands of Scots pine (Pinus sylvestris L.) and European beech (Fagus sylvatica L.) along a gradient of productivity through Europe. European Journal of Forest Research, 134, 927-947. 
Prietzel J., Rehfuess K.E., Stetter U., Pretzsch, H. (2008) Changes of soil chemistry, stand nutrition, and stand growth at two Scots pine (Pinus sylvestris L.) sites in Central Europe during 40 years after fertilization, liming, and lupine introduction. European Journal of Forest Research, 127, 43-61.

Primicia I. (2012) Influence of thinning and canopy type on the internal nutrient cycling and the secondary growth of Pinus sylvetris L. in a mixed forest in the Pyrenees. PhD thesis. Universidad Pública de Navarra, Pamplona, Spain. 144 p.

Primicia I., Camarero J.J., Imbert J.B., Castillo F.J. (2013) Effects of thinning and canopy type on growth dynamics of Pinus sylvestris: inter-annual variations and intra-annual interactions with microclimate. European Journal of Forest Research, 132, 121-135.

Primicia I., Imbert J.B., Traver M.C., Castillo F.J. (2014) Inter-specific competition and management modify the morphology, nutrient content and resorption in Scots pine needles. European Journal of Forest Research, 133, 141-151.

Puertas F. (2001) Sitios de ensayo de claras de masas de Pino silvestre en Navarra (Garde y Aspurz). Servicio de Conservación de la Biodiversidad. In Spanish. Departamento de Medio Ambiente Ordenación del Territorio y Vivienda (DMOTV), Pamplona, Navarre, Spain.

Rayner N.A., Parker D.E., Horton E.B., Folland C.K., Alexander L.V., Rowell D.P., Kent E.C., Kaplan A. (2003) Global analyses of sea surface temperature, sea ice, and night marine air temperature since the late nineteenth century. Journal of Geophysical Research: Atmospheres, 108, 4407-4444.

Reed S.C., Townsend A.R., Davidson E.A., Cleveland C.C. (2012) Stoichiometric patterns in foliar nutrient resorption across multiple scales. New Phytologist, 196, 173-180.

Reich P.B., Borchert R. (1984) Water stress and tree phenology in a tropical dry forest in the lowlands of Costa Rica. Journal of Ecology, 72, 61-74.

Reich P.B., Oleksyn J. (2004) Global patterns of plant leaf N and P in relation to temperature and latitude. Proceedings of the National Academy of Sciences, 101, 11001-11006.

Reich P.B., Oleksyn J., Modrzynski J.,Mrozinski P., Hobbie S.E., Eissenstat D.M., Chorover J., Chadwick O.A., Hale C.M., Tjoelker M.G. (2005) Linking litter calcium, earthworms and soil properties: a common garden test with 14 tree species. Ecology Letters, 8, 811-818.

Reich P.B., Sendall K.M., Stefanski A., Rich R.L., Hobbie S.E., Montgomery R.A. (2018). Effects of climate warming on photosynthesis in boreal tree species depend on soil moisture. Nature, 562, 263-267. 
Richards L.A. (1954) Diagnosis and Improvement of Saline and Alkaline Soils. USDA Handbook No. 60. U.S. Department of Agriculture, Washington DC),

Rivas-Ubach A., Sardans J., Pérez-Trujillo M., EstiarteM., Peñuelas J. (2012) Strong relationship between elemental stoichiometry and metabolome in plants. Proceedings of the National Academy of Sciences, 109, 4181-4186.

Rodó X., Baert E., Comin F. (1997) Variations in seasonal rainfall in Southern Europe during the present century: relationships with the North Atlantic Oscillation and the El NiñoSouthern Oscillation. Climate Dynamics, 13, 275-284.

Romero R., Guijarro J.A., Ramis C., Alonso S. (1998) A 30-year (1964-1993) daily rainfall data base for the Spanish Mediterranean regions: first exploratory study. International Journal of Climatology, 18, 541-560.

Rothe A., Binkley D. (2001) Nutritional interactions in mixed species forests: a synthesis. Canadian Journal of Forest Research, 31, 1855-1870.

Rozas V., Camarero J.J., Sangüesa-Barreda G., Souto M., García-González I. (2015) Summer drought and ENSO-related cloudiness distinctly drive Fagus sylvatica growth near the species rear-edge in northern Spain. Agricultural and Forest Meteorology, 201, 153164.

Sánchez-Salguero R., Camarero J.J., Hevia A., Madrigal-González J., Linares J.C., Ballesteros-Canovas J.A., Sánchez-Miranda A., Alfaro-Sánchez R., Sangüesa-Barreda G., Galván J.D., Gutiérrez E., Génova M., Rigling A. (2015) What drives growth of Scots pine in continental Mediterranean climates: Drought, low temperature of both? Agricultural and Forest Meteorology, 206, 151-162.

Santa Regina I., Tarazona T. (2001) Nutrient pools to the soil through organic matter and throughfall under a Scots pine plantation in the Sierra de la Demanda, Spain. European Journal of Soil Biology, 37, 125-133.

Sardans J., Peñuelas J. (2007) Drought changes phosphorus and potassium accumulation patterns in an evergreen Mediterranean forest. Functional Ecology, 21, 191-201.

Sardans J., Peñuelas J., Coll M., Vayreda J., Rivas-Ubach A. (2012a) Stoichiometry of potassium is largely determined by water availability and growth in Catalonian forests. Functional Ecology, 26, 1077-1089.

Sardans J., Rivas-Ubach A., Peñuelas J. (2012b) The elemental stoichiometry of aquatic and terrestrial ecosystems and its relationship with organism life style and ecosystem structure and function: a review. Biogeochemistry, 111, 1-39. 
Sardans J., Rivas-Ubach A., Estiarte M., Ogaya R., Peñuelas J. (2013) Field-simulated droughts affect elemental leaf stoichiometry in Mediterranean forests and shrublands. Acta Oecologica, 50, 20-31.

Sardans J., Janssens I.A., Alonso R., Veresoglou S.D., Rilling M.C., Sanders T.G.M., Carnicer J., Fillella I., Farré-Armengol G., Peñuelas J. (2015) Foliar elemental composition of European forest tree species are associated with evolutionary traits and present environmental and competitive conditions. Global Ecology and Biogeography, 24, 240-255.

Sardans J., Grau O., Chen H.Y.H., Janssens I.A., Ciais P., Piao S., Peñuelas J. (2017) Changes in nutrient concentrations of leaves and roots in response to global change factors. Global Change Biology, 23, 1-8.

Schmitz A., Sanders T.G.M., Bolte A., Bussoti F., Dirnböck T., Johnson J., Peñuelas J., Pollastrini M., Prescher A.K., Sardans J., Verstraeten A., de Vries W. (2019) Responses of forest ecosystems in Europe to decreasing nitrogen deposition. Environmental Pollution, 244, 980-994.

Schneider T., Keiblinger K.M., Schmid E., Sterflinger-Gleixner K., Ellersdorfer G., Roschitzki B., Richter A., Eberl L., Zechmeister-Boltenstern S., Riedel K. (2012) Who is who in litter decomposition? Metaproteomics reveals major microbial players and their biogeochemical functions. ISME Journal, 6, 1749-1762.

Shipley B. (2016) Cause and Correlation in Biology: A User's Guide to Path Analysis, Structural Equations and Causal Inference with R. Cambridge University Press.

Sohrt J., Lang F., Weiler M. (2017) Quantifying components of the phosphorus cycle in temperate forests. WIREs Water, 4, e1243.

Staelens J., Nachtergale L., De Schrijver A., Vanhellemont M., Wuyts K., Verheyen K. (2011) Spatio-temporal litterfall dynamics in a 60-year-old mixed deciduous forest. Annals of Forest Science, 68, 89-98.

Starr M., Saarsalmi A., Hokkanen T., Merilä P., Helmisaari H.S. (2005) Models of litterfall production for Scots pine (Pinus sylvestris L.) in Finland using stand, site and climate factors. Forest Ecology and Management, 205, 215-225.

Stenseth N.C., Mysterud A., Ottersen G., Hurrell J.W., Chan K.S., Lima M. (2002) Ecological effects of climate fluctuations. Science, 297, 1292-1296.

Stenseth N.C.,Ottersen G.,Hurrell J.W., Mysterud A.,Lima M., Chan K.S.,Yoccoz N.G., Ådlandsvik B. (2003) Studying climate effects on ecology through the use of climate 
indices: the North Atlantic Oscillation, El Niño-Southern Oscillation and beyond. Proceedings of the Royal Society London B, 270, 2087-2096.

Sterner R.W., Elser J.J. (2002) Ecological stoichiometry the biology of elements from molecules to the biosphere. Princeton University Press, Princeton, USA, pp. 439.

Sundarapandian S.M., Swamy P.S. (1999) Litter production and leaf-litter decomposition of selected tree species in tropical forests at Kodayar in the Western Ghats India. Forest Ecology and Management, 123, 231-244.

Talkner U., Janse M., Beese F.O. (2009) Soil phosphorus status and turnover in centralEuropean beech forest ecosystems with differing tree species diversity. European journal if Soil Science, 60, 338-346.

Talkner U., Meiwes K.J., Potocić N., Seletković I., Cools N., De Vos B., Rautio P. (2015) Phosphorus nutrition of beech (Fagus sylvatica L.) is decreasing in Europe. Annals of Forest Science, 72, 919-928.

Thornthwaite C.W., Mather J.R. (1957) Instruction and tables for computing potential evapotranspiration and the water balance. Publications in Climatology. Laboratory of Climatology Drexel Institute of Technology, 10, 185-311.

Trouet V., Van Oldenborgh G.J. (2013) KNMI Climate Explorer. A web-based research tool for high-resolution paleoclimatology. Tree-Ring Research, 69, 3-13.

Urbina I., Sardans J., Grau O., Beierkuhnlein C., Jentsch A., Kreyling J., Peñuelas J. (2017) Plant community composition affects the species biogeochemical niche. Ecosphere, $\mathbf{8}$, e01801.

USDA - Soil Conseervation Service (1972). Investigación de suelos. Métodos de laboratorio y procedimientos para recoger muestra. Trillas, México D.F.

Vicente-Serrano S.M., Beguería S., López-Moreno J.I. (2010) A multiscalar drought index sensitive to global warming: the standardized precipitation evapotranspiration index. Journal of Climate, 23, 1696-1718.

Vincent A.G., Vestergren J., Gröbner G., Persson P., Schleucher J., Giesler R. (2013) Soil organic phosphorus transformations in a boreal forest chronosequence. Plant Soil, 367, $149-162$.

Vitousek P. (1982) Nutrient cycling and nutrient use efficiency. American Naturalist, 119, $553-572$.

Wang Q., Wang S., Huang Y. (2008) Comparisons of litterfall, litter decomposition and nutrient return in a monoculture Cunninghamia lanceolata and a mixed stand in southern China. Forest Ecology and Management, 255, 1210-1218. 
Wang S., Huang J., He Y., Guan Y. (2014a) Combined effects of the Pacific Decadal Oscillation and El Niño-Southern Oscillation on global land dry-wet changes. Scientific Reports, 4, 6651.

Wang X., Piao S., Ciais P., Friedlingstein P., Myneni R.B., Cox P., Heimann M., Miller J., Peng S., Wang T., Yang H, Chen A. (2014). A two-fold increase of carbon cycle sensitivity to tropical temperature variations. Nature, 506, 212-215.

Waterhouse J.S., Switsur V.R., Barker A.C., Carter A.H.C., Hemming D.L., Loader N.J., Robertson I. (2004) Northern European trees show a progressively diminishing response to increasing atmospheric carbon dioxide concentrations. Quaternary Science Review, 23, 803-810.

Wirth C., Schulze E.D., Kusznetova V., Milyukova I., Hardes G., Siry M., Schulze B., Vygodskaya N.N. (2002) Comparing the influence of site quality, stand age, fire and climate on aboveground tree production in Siberian Scots pine forests. Tree Physiology, 22, 537-552.

Wright J., Cornejo F.H. (1990) Seasonal drought and leaf fall in a tropical forest. Ecology, 71, 1165-1175.

Wu Z., Huang N.E., Long S.R., Peng C.K. (2007) On the trend, detrending, and variability of nonlinear and nonstationary time series. Proceedings of the National Academy of Sciences, 104, 14889-14894.

Wu Z., Huang N.E. (2009) Ensemble empirical mode decomposition: a noise-assisted data analysis method. Advances in Adaptive Data Analysis, 1, 1-41.

Xu X., Thornton P.E., Post W.M. (2013) A global analysis of soil microbial biomass carbon, nitrogen and phosphorus in terrestrial ecosystems. Global Ecology and Biogeography, 22, 737-749.

Yuan Z.Y., Chen H.Y.H. (2009a) Global trends in senesced-leaf nitrogen and phosphorus. Global Ecology and Biogeographt, 18, 532-542.

Yuan Z.Y., Chen H.Y.H. (2009b) Global-scale patterns of nutrient resorption associated with latitude, temperature and precipitation. Global Ecology and Biogeography, 18, 11-18. Yuan Z.Y., Chen H.Y.H. (2015) Decoupling of nitrogen and phosphorus in terrestrial plants associated with global changes. Nature Climate Change, 5, 465-469.

Zechmeister-Boltenstern S., Keiblinger K.M., Mooshammer M., Peñuelas J., Richter A., Sardans J., Wanek W. (2015) The application of ecological stoichiometry to plantmicrobial-soil organic matter transformations. Ecological Monographs, 85, 133-155. 
Zhang D.Q., Hui D.F., Luo Y.Q., Zhou G.Y. (2008) Rates of litter decomposition in terrestrial ecosystems: global patterns and controlling factors. Journal of Plant Ecology, 1, 85-93.

Zhang H., Yuan W., Dong W., Liu S. (2014) Seasonal patterns of litterfall in forest ecosystem worldwide. Ecological Complexity, 20, 240-247.

Zhang X., Chen Z. (2017) A new method to remove the tree growth trend based on ensemble empirical mode decomposition. Trees, 31, 405-413. 


\section{TABLES}

Table 1. Sites and stands characteristics (mean \pm standard error) measured in 2014. Stands descriptors were taken from Puertas (2001) and Iriarte and Puertas (2003).

\begin{tabular}{|c|c|c|}
\hline Site & Mediterranean site & Continental site \\
\hline Latitude & $42^{\circ} 42^{\prime} 31^{\prime \prime} \mathrm{N}$ & $42^{\circ} 48^{\prime} 50^{\prime} \mathrm{N}$ \\
\hline Longitude & $1^{\circ} 8,40, ' \mathrm{~W}$ & $52 ’ 30 ’, \mathrm{~W}$ \\
\hline Altitude (m a.s.1.) & 625 & 1335 \\
\hline Climate type (Papadakis, 1970) & Cold wet Mediterranean & Cold wet continental \\
\hline Mean annual temperature $\left({ }^{\circ} \mathrm{C}\right)^{a}$ & $11.9 \pm 0.1$ & $9.3 \pm 0.1$ \\
\hline Total annual precipitation $(\mathrm{mm})^{a}$ & $913 \pm 23$ & $1346 \pm 61$ \\
\hline Soil & Haplic Alisol & Dystric Cambisol \\
\hline Slope $(\%)$ & 7 & 40 \\
\hline Density $\left(\text { stems ha }{ }^{-1}\right)^{b}$ & $2400 \pm 301$ & $2019 \pm 212$ \\
\hline Total basal area $\left(\mathrm{m}^{2} \mathrm{ha}^{-1}\right)$ & $57.5 \pm 2.25$ & $56.0 \pm 6.3$ \\
\hline Tree species richness & 18 & 10 \\
\hline Density proportion of $P$. sylvestris (\%) & $69.34 \pm 0.02$ & $85.22 \pm 0.06$ \\
\hline Density proportion of $F$. sylvatica (\%) & $11.73 \pm 0.04$ & $13.71 \pm 0.05$ \\
\hline Site Index at stand age 80 years $(\mathrm{m})^{\mathrm{c}}$ & 29 & 23 \\
\hline Stand Age in 2017 (years) $^{c}$ & $50 \pm 2.3$ & $55 \pm 2.1$ \\
\hline Dominant height $(\mathrm{m})^{\mathrm{c}, \mathrm{d}}$ & $20.4 \pm 0.3$ & $17.3 \pm 0.9$ \\
\hline Mean dbh P. sylvestris $(\mathrm{cm})^{\mathrm{e}}$ & $17.2 \pm 1.1$ & $17.9 \pm 0.8$ \\
\hline Mean dbh F. sylvestris $(\mathrm{cm})^{\mathrm{e}}$ & $8.5 \pm 0.5$ & $5.0 \pm 1.1$ \\
\hline
\end{tabular}

${ }^{a}$ Referred to the period 1980-2017.

${ }^{\mathrm{b}}$ Trees with a diameter at breast height $(1.30 \mathrm{~m}, \mathrm{dbh})>7.5 \mathrm{~cm}$.

${ }^{c}$ Referred to $P$. sylvestris.

${ }^{d}$ Measured averaging $(n=100)$ the height of the thickest dominant trees per hectare.

${ }^{\mathrm{e}}$ Measured by double cross measurement. 
Table 2. Soil properties of the top mineral soil (mean \pm SE) at the study sites.

\begin{tabular}{lcc}
\hline & Mediterranean site & Continental site \\
\cline { 2 - 3 } Texture $^{\mathrm{a}}$ & Silt loam & Loam \\
Density $\left(\mathrm{g} \mathrm{cm}^{-3}\right)$ & 0.96 & 0.76 \\
$\mathrm{pH} 1: 2.5 \mathrm{H}_{2} \mathrm{O}$ & $5.05 \pm 0.06$ & $5.20 \pm 0.05$ \\
$\mathrm{CEC}\left(\mathrm{cmol}^{+} \mathrm{kg}^{-1}\right)$ & $11.21 \pm 0.39$ & $20.19 \pm 1.38$ \\
Organic Matter $(\%)$ & $9.22 \pm 0.41$ & $9.57 \pm 0.62$ \\
Organic C $\left(\mathrm{mg} \mathrm{g}^{-1}\right)^{\mathrm{b}}$ & $53.12 \pm 2.75$ & $52.62 \pm 2.36$ \\
Organic $\mathrm{N}\left(\mathrm{mg} \mathrm{g}^{-1}\right)^{\mathrm{b}}$ & $2.62 \pm 0.12$ & $2.39 \pm 0.08$ \\
Available $\mathrm{P}\left(\mathrm{mg} \mathrm{g}^{-1}\right)^{\mathrm{c}}$ & $0.018 \pm 0.001$ & $0.025 \pm 0.002$ \\
Available K $\left(\mathrm{mg} \mathrm{g}^{-1}\right)^{\mathrm{c}}$ & $0.114 \pm 0.004$ & $0.146 \pm 0.007$ \\
$\mathrm{C} / \mathrm{N}$ & $20.68 \pm 0.51$ & $22.43 \pm 1.13$ \\
$\mathrm{~N} / \mathrm{P}$ & $196.9 \pm 13.9$ & $139.3 \pm 22.4$ \\
\hline
\end{tabular}

${ }^{a}$ Based on USDA classification.

${ }^{\mathrm{b}}$ Organic C (Walkley-Black method, USDA, 1972), organic N (Kjeldahl),

${ }^{c}$ Available P (Olsen, Kuo, 1996), available K (mass spectrometry, Richards 1954). 
Table 3. Litterfall production (mean \pm standard error; $\mathrm{kg} \mathrm{ha}^{-1}$ ) of late summer and autumn at both study sites separated by months, fractions and localities. Different letters correspond to significant differences among months within litterfall fraction and site $(p<0.05$, Tukey test).

\begin{tabular}{llccccccc}
\hline Litter fraction & Site & Total & August & September & October & November & $F$ & $p$-value \\
\hline Scots pine needles & MED & $1261.9 \pm 48.1$ & $476.9 \pm 23.9 \mathrm{a}$ & $424.2 \pm 18.7 \mathrm{a}$ & $245.0 \pm 14.9 \mathrm{~b}$ & $115.7 \pm 1.4 \mathrm{c}$ & 82.16 & $<0.0001$ \\
& CONT & $1618.2 \pm 191.4$ & $330.5 \pm 26.2 \mathrm{a}$ & $604.3 \pm 56.2 \mathrm{~b}$ & $683.4 \pm 109.5 \mathrm{~b}$ & - & 18.51 & $<0.0001$ \\
Beech leaves & MED & $582.0 \pm 95.2$ & $11.2 \pm 2.1 \mathrm{a}$ & $19.1 \pm 2.3 \mathrm{a}$ & $121.3 \pm 30.4 \mathrm{~b}$ & $430.3 \pm 68.9 \mathrm{c}$ & 124.51 & $<0.0001$ \\
& CONT & $7.6 \pm 2.0$ & $0.7 \pm 0.3 \mathrm{a}$ & $0.5 \pm 0.2 \mathrm{a}$ & $6.4 \pm 1.9 \mathrm{~b}$ & - & 43.88 & $<0.0001$ \\
Other broadleaves & MED & $142.8 \pm 29.7$ & $14.7 \pm 2.9 \mathrm{ab}$ & $13.9 \pm 3.9 \mathrm{a}$ & $58.8 \pm 6.1 \mathrm{a}$ & $55.2 \pm 18.9 \mathrm{c}$ & 6.77 & 0.0003 \\
& CONT & $11.9 \pm 2.8$ & $3.3 \pm 0.4 \mathrm{a}$ & $2.6 \pm 0.4 \mathrm{a}$ & $6.0 \pm 2.1 \mathrm{~b}$ & - & 3.57 & 0.0314 \\
Scots pine branches & MED & $394.6 \pm 17.5$ & $175.2 \pm 30.7 \mathrm{a}$ & $100.5 \pm 16.5 \mathrm{ab}$ & $74.4 \pm 11.4 \mathrm{~b}$ & $44.5 \pm 24.4 \mathrm{~b}$ & 6.59 & $<0.0001$ \\
& CONT & $110.9 \pm 14.0$ & $52.4 \pm 13.2$ & $24.6 \pm 6.7$ & $33.9 \pm 8.2$ & - & 2.10 & 0.1272 \\
Miscellaneous & MED & $400.4 \pm 28.9$ & $169.6 \pm 5.7 \mathrm{a}$ & $84.0 \pm 5.6 \mathrm{bc}$ & $97.1 \pm 9.6 \mathrm{~b}$ & $49.6 \pm 11.2 \mathrm{c}$ & 18.69 & $<0.0001$ \\
& CONT & $247.1 \pm 42.9$ & $123.0 \pm 27.3 \mathrm{a}$ & $58.0 \pm 7.6 \mathrm{~b}$ & $66.1 \pm 8.4 \mathrm{~b}$ & - & 12.73 & $<0.0001$ \\
\hline
\end{tabular}


Table 4. Nutrient concentration and ratios (mean \pm standard error) of leaf fractions of litterfall of Scots pine and European beech at the two study sites: Mediterranean site (MED) and continental site (CONT). Significant differences between sites $(p<0.05$, ANOVA) are shown with asterisks.

\begin{tabular}{lcccc}
\hline & \multicolumn{2}{c}{ Pinus sylvestris } & \multicolumn{2}{c}{ Fagus sylvatica } \\
\cline { 2 - 5 } & MED site & CONT site & MED site & CONT site \\
\hline$[\mathrm{N}]\left(\mathrm{mg} \mathrm{g}^{-1}\right)$ & $7.04 \pm 0.31$ & $6.22 \pm 0.22$ & $14.01 \pm 0.52$ & $9.39 \pm 0.43^{*}$ \\
{$[\mathrm{P}]\left(\mathrm{mg} \mathrm{g}^{-1}\right)$} & $0.23 \pm 0.01$ & $0.39 \pm 0.01^{*}$ & $0.37 \pm 0.02$ & $0.42 \pm 0.02$ \\
{$[\mathrm{~K}]\left(\mathrm{mg} \mathrm{g}^{-1}\right)$} & $2.32 \pm 0.10$ & $2.35 \pm 0.10$ & $5.40 \pm 0.33$ & $3.67 \pm 0.31^{*}$ \\
$\mathrm{~N}: \mathrm{P}$ & $32.36 \pm 1.04$ & $16.37 \pm 0.48^{*}$ & $39.80 \pm 1.41$ & $23.17 \pm 1.06^{*}$ \\
$\mathrm{~N}: \mathrm{K}$ & $3.12 \pm 0.09$ & $2.75 \pm 0.11$ & $2.78 \pm 0.12$ & $3.25 \pm 0.26$ \\
$\mathrm{P}: \mathrm{K}$ & $0.098 \pm 0.003$ & $0.170 \pm 0.005^{*}$ & $0.074 \pm 0.005$ & $0.150 \pm 0.013^{*}$ \\
\hline
\end{tabular}


(a)

BOTH SITES

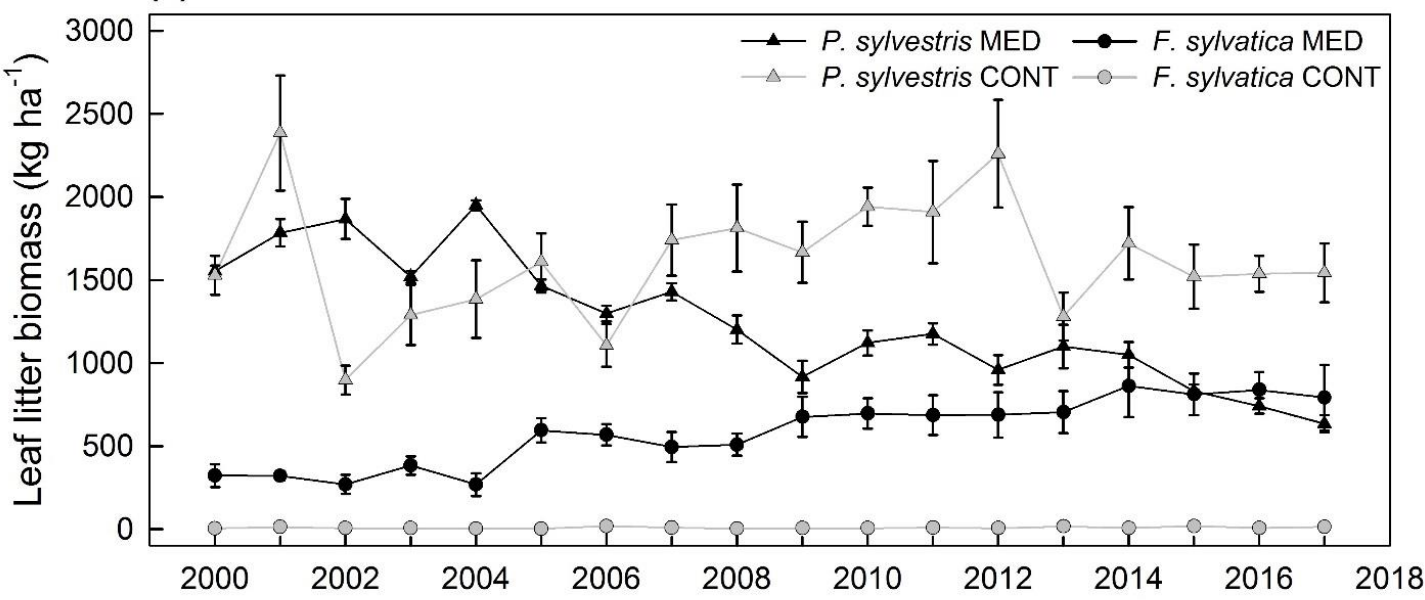

(b)

\section{MEDITERRANEAN SITE}
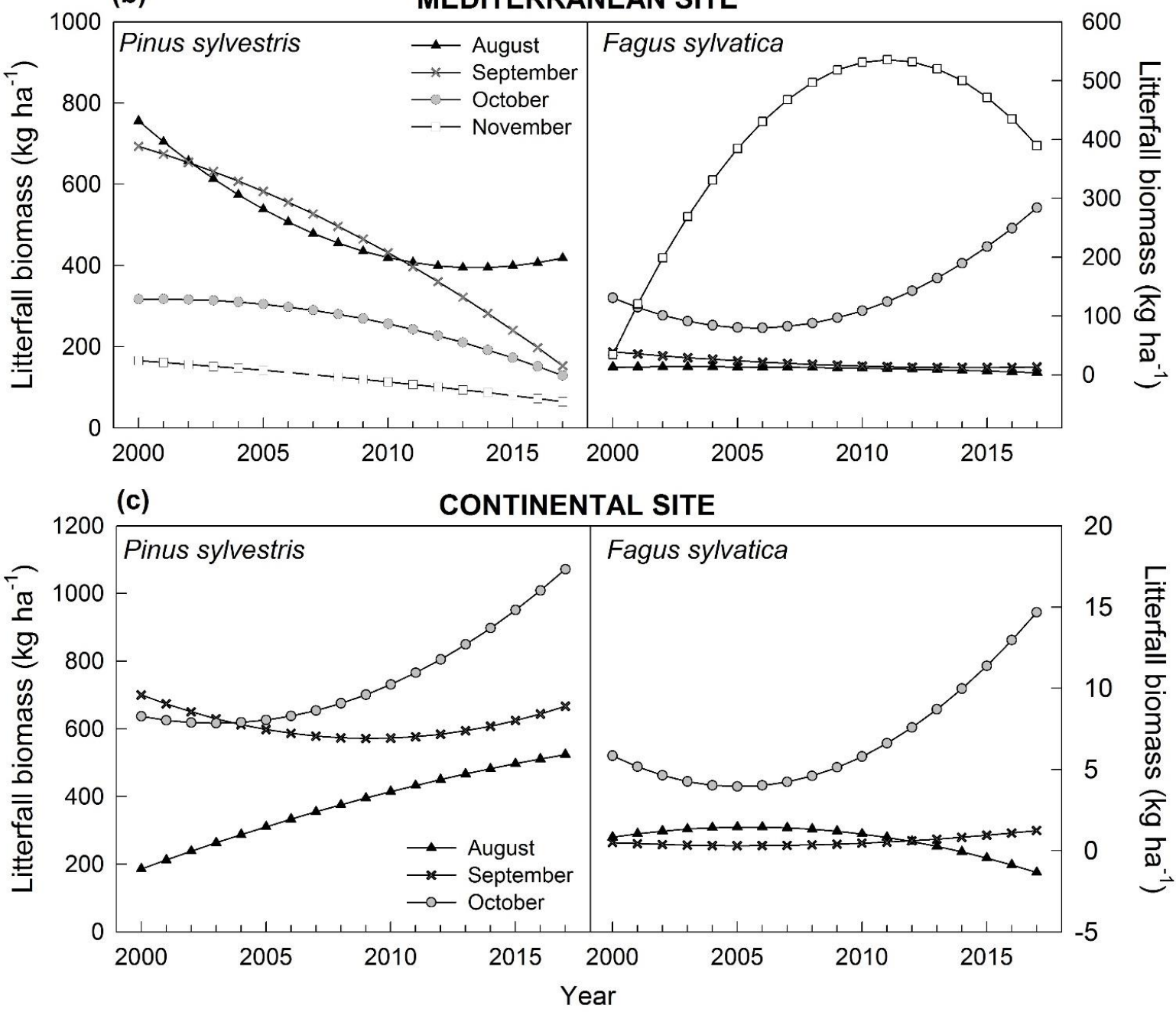

Figure 1. Evolution of whole-autumn leaf litter biomass (A) and trends of monthly leaf litter production at the Mediterranean site (B) and continental site (C). Trends were extracted by means of ensemble empirical mode decomposition (EEMD) (see section 2.4.). Different symbols represent different months. 


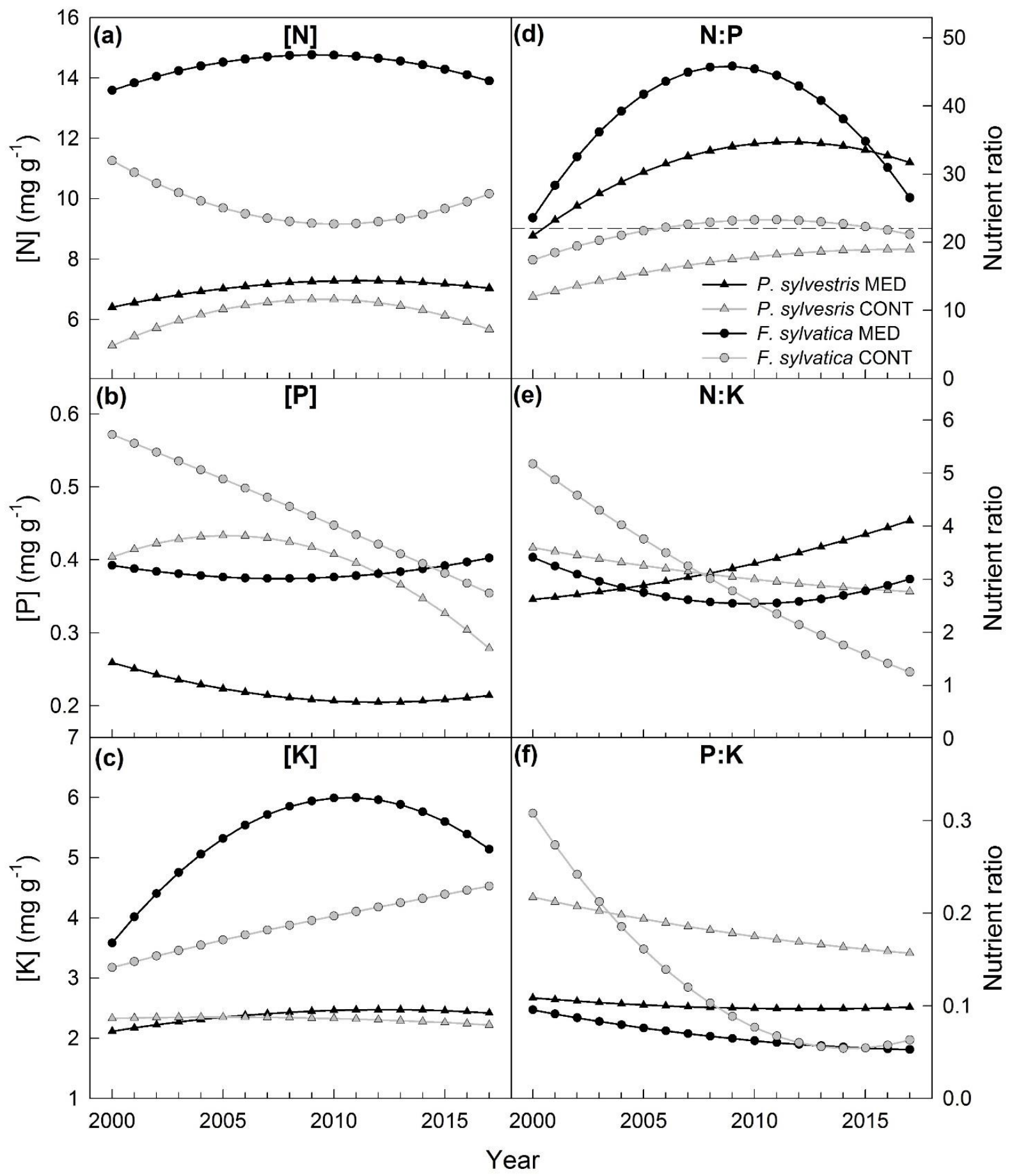

Figure 2. Trends of different nutrient ratios in Scots pine needles (triangles) and European beech leaves (circles) in the litterfall collected at the two study sites: Mediterranean site (MED, black) and continental site (CONT, grey). Trends were extracted by means of ensemble empirical mode decomposition (EEMD) (see section 2.4.). The horizontal dash line in $\mathrm{D}$ graph represents the $\mathrm{N}: \mathrm{P}$ threshold value above which litterfall decomposition has been proposed to be P-limited (Güsewell \& Freeman 2005). 


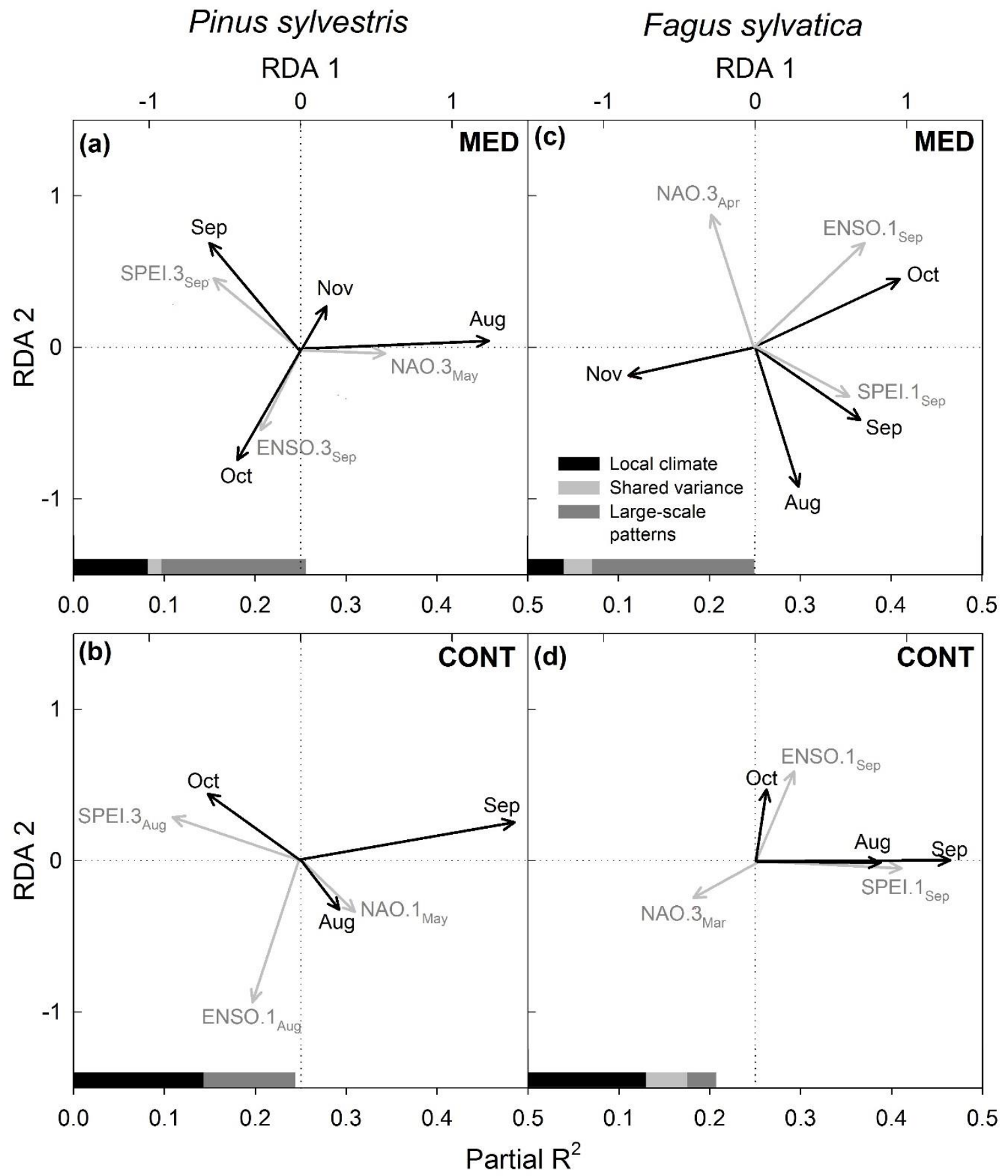

Figure 3. Redundancy analysis (RDA) based on experimental plots as cases and climate variables as predictive matrix and response matrix of trendless components (TCs) of leaf litter monthly production of Scots pine at the Mediterranean site (A) and at the continental site (B), and European beech at the Mediterranean site (C) and at the continental site (D). Climate

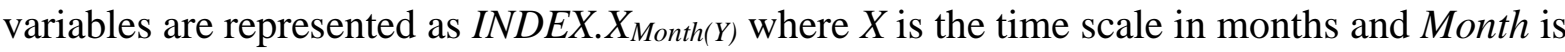
the last month considered for index. Bars at the bottom of every graph represent partial $\mathrm{R}^{2}$ of local climate (black), large-scale circulation patterns (dark grey) and shared variance (light grey). 
Pinus sylvestris

RDA 1

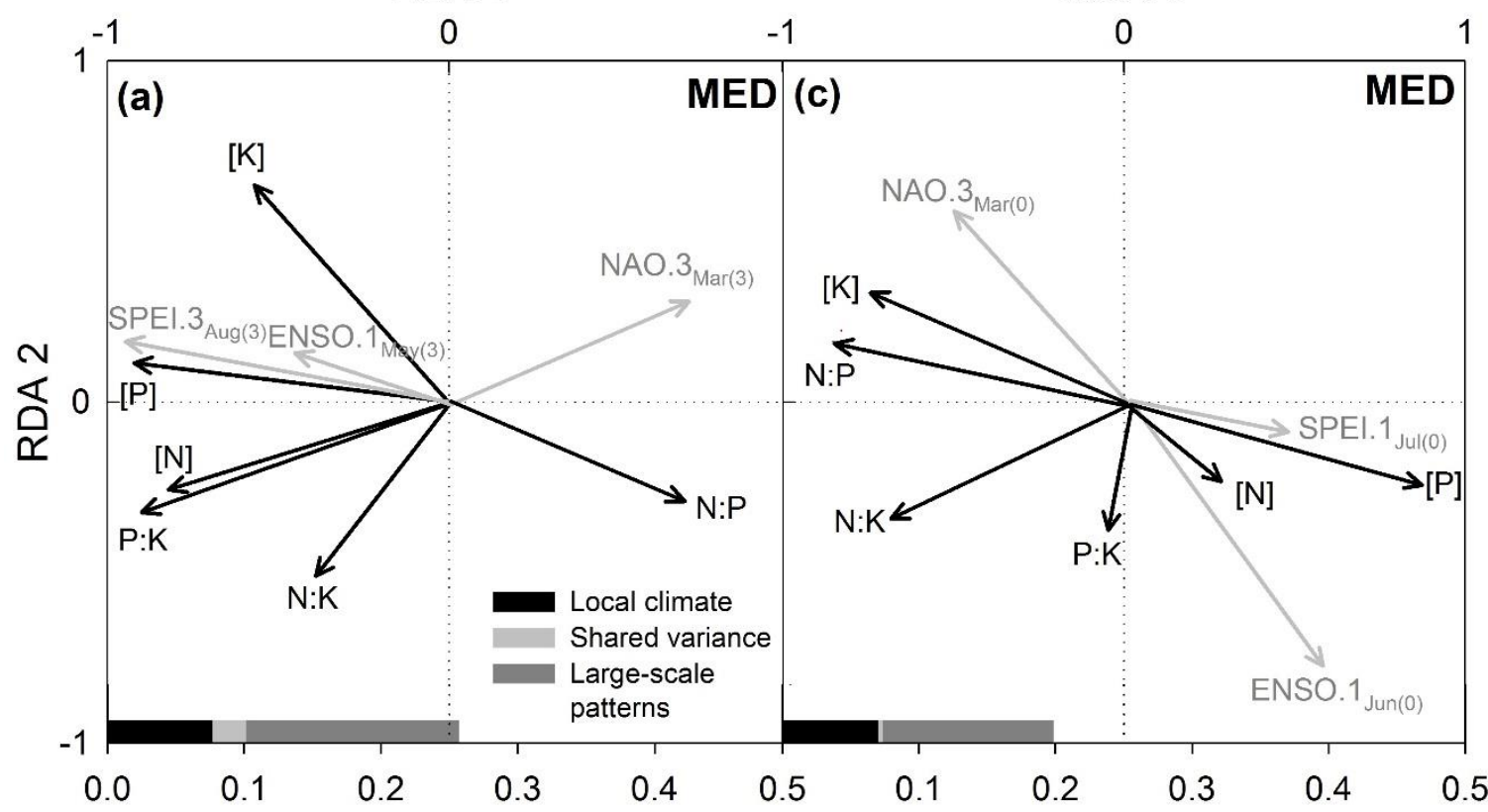

Fagus sylvatica

RDA 1

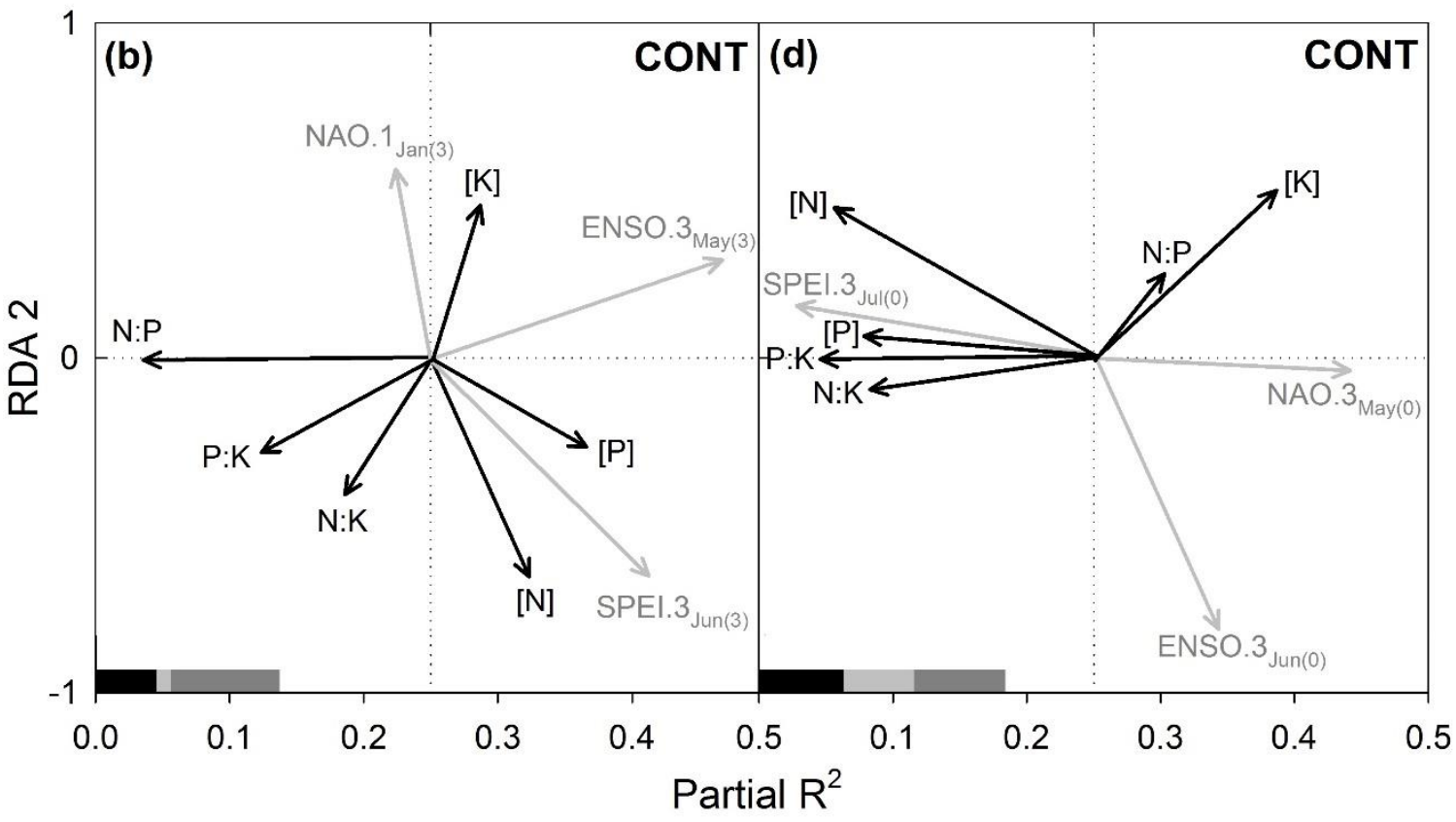

Figure 4. Redundancy analysis (RDA) based on experimental plots as cases and climate variables as predictive matrix and response matrix of trendless components (TCs) of concentrations of N, P and $\mathrm{K}$ and their stoichiometric relationships in Scots pine senescent needles at the Mediterranean site (A) and at the continental site (B), and European beech senesced leaves at the Mediterranean site (C) and at the continental site (D). Climate variables are represented as INDEX. $X_{\text {Month }(Y)}$ where $X$ is the time scale in months, Month is the last month considered for index calculation and $Y$ is the time lag in years. Bars at the bottom of every graph represent partial $\mathrm{R}^{2}$ of local climate (black), large-scale circulation patterns (dark grey) and shared variance (light grey). 


\section{Pinus sylvestris}
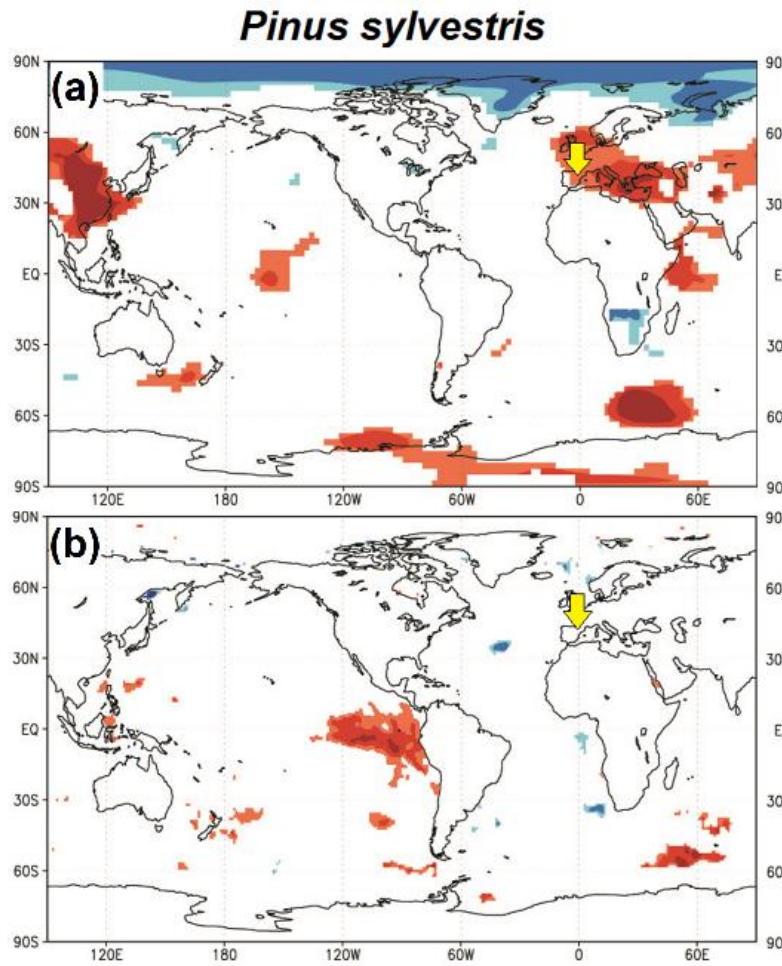

(b)
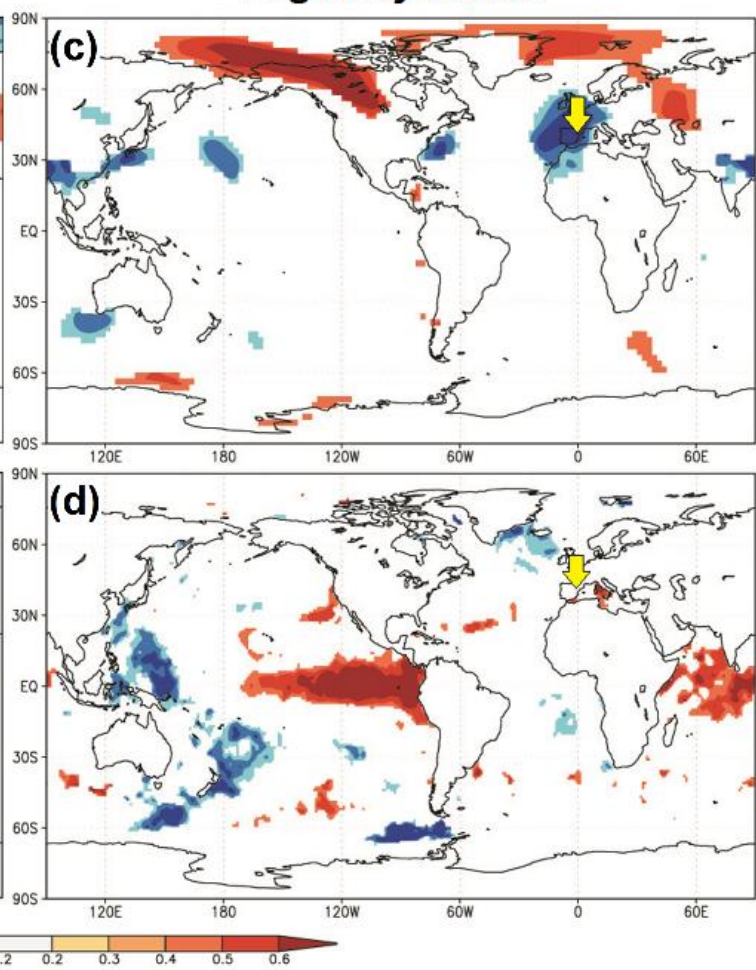

Figure 5. Spatiotemporal correlations between detrended NCEP/NCAR R1 sea level pressure (SLP, above), detrended HadISST1 sea surface temperature (SST; bottom) and leaf litter production trendless components (TCs) the time period 2000 - 2017: (A) March to April SLP - August Scots pine needle fall at the Mediterranean site; (B) May to July SST - October Scots pine needle fall at the Mediterranean site; (C) previous November SLP - October European beech leaf fall at the continental site; (D) July to September SST - September European beech leaf litter production at the Mediterranean site. Only correlations with $p<0.1$ are shown. Yellow arrows indicate location of the study sites. 
Pinus sylvestris
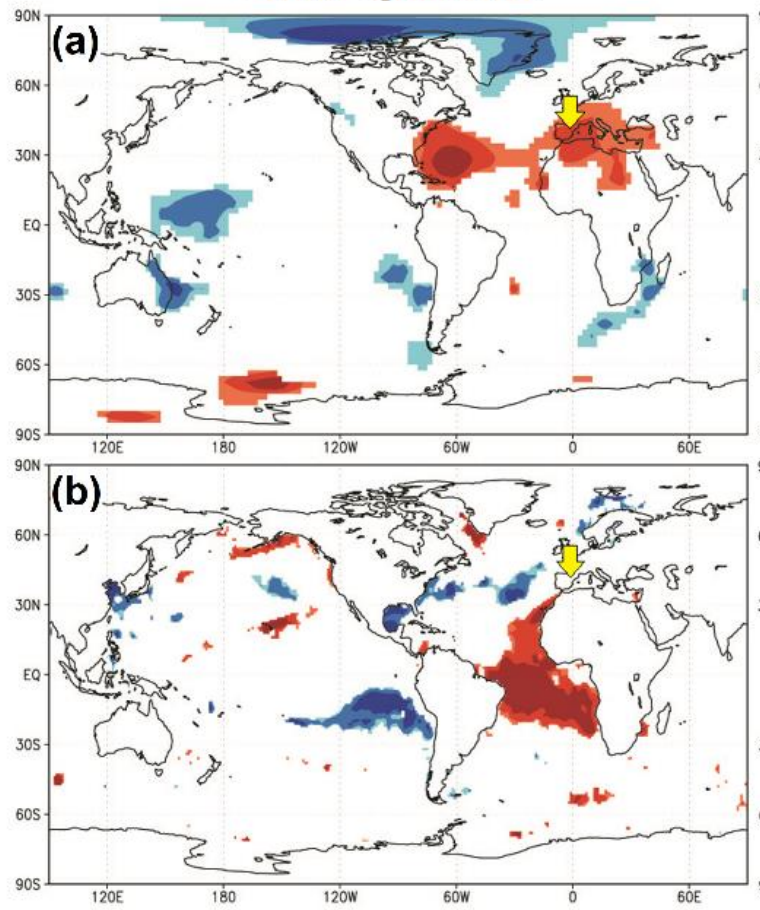

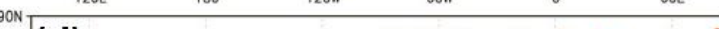

Fagus sylvatica

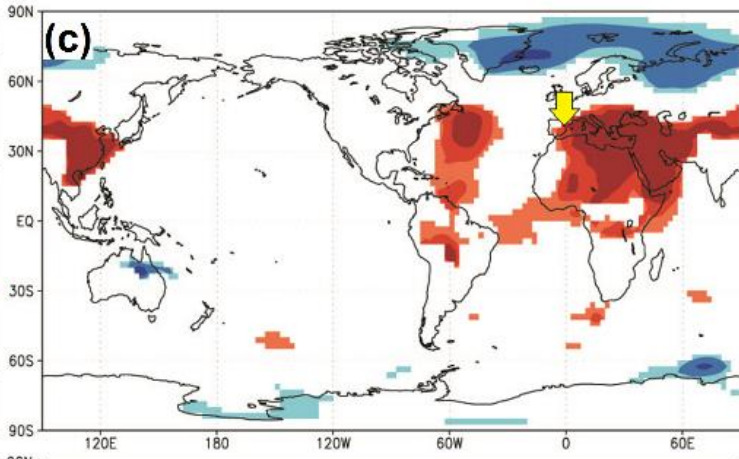

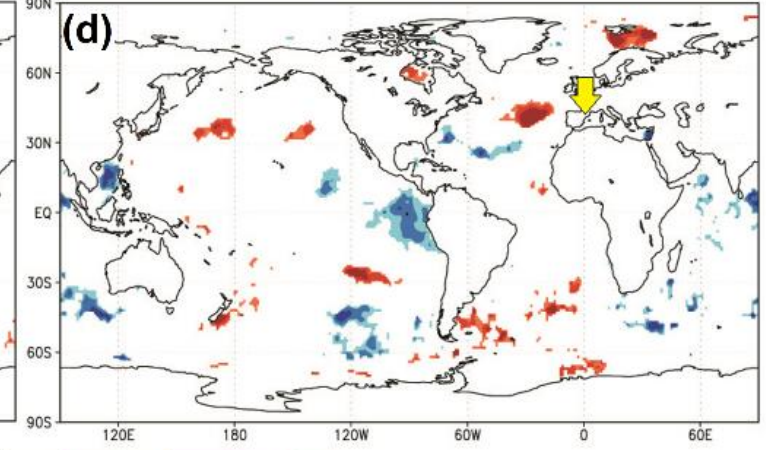

Figure 6. Spatiotemporal correlations between detrended NCEP/NCAR R1 sea level pressure (SLP, above), detrended HadISST1 sea surface temperature (SST; bottom) and leaf litter N:P stoichiometric trendless components (TCs) for the time period 2000 - 2017: (A) 3year lagged March SLP - Scots pine needle litter N:P ratio at the continental site; (B) 3-year lagged January to March SST - Scots pine needle litter N:P ratio at the continental site; (C) current February SLP - European beech leaf litter N:P ratio at the Mediterranean site; (D) current September SST - European beech leaf litter N:P ratio at the continental site. Only correlations with $\mathrm{p}<0.1$ are shown. Yellow arrows indicate location of the study sites. 


\section{Pinus sylvestris}
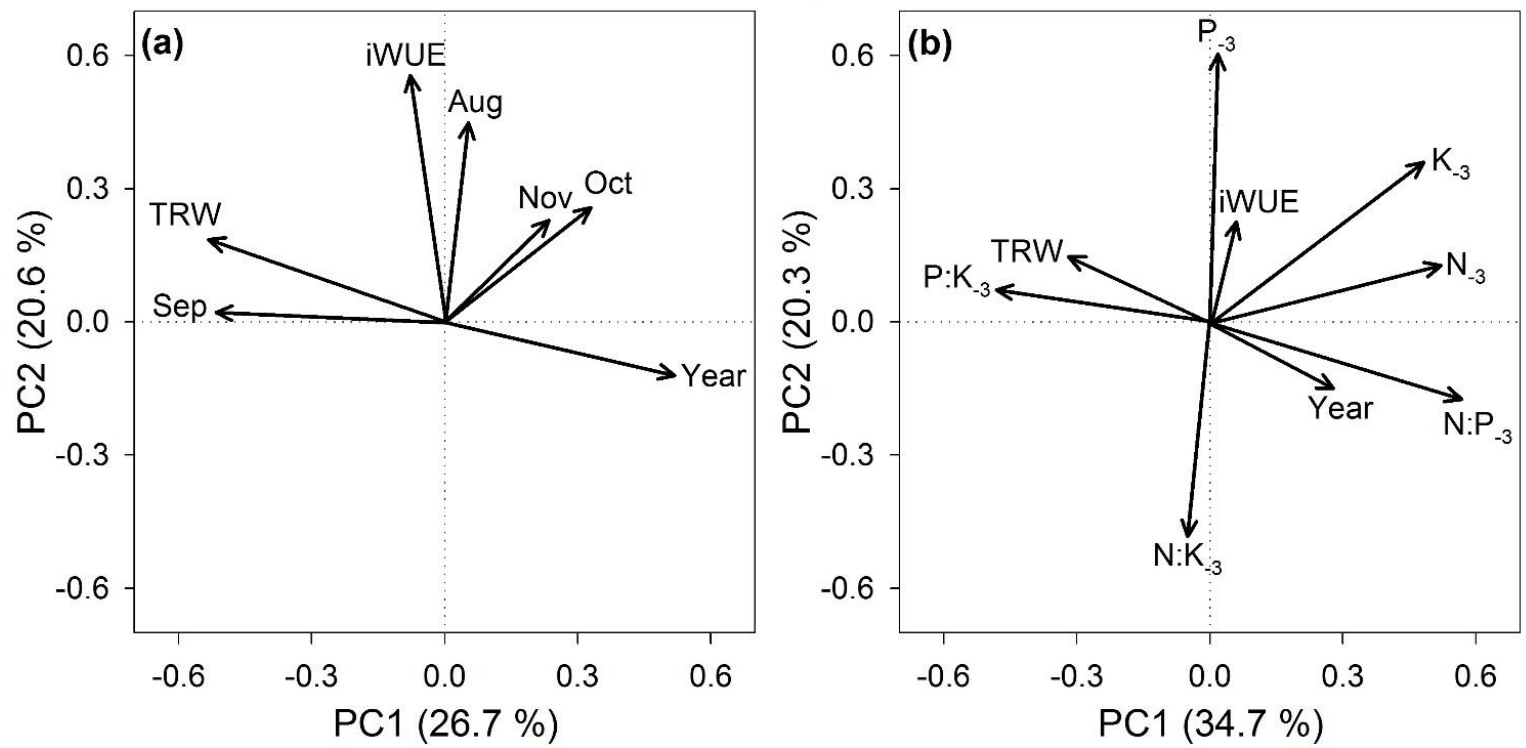

Figure 7. (A) Principal component analysis (PCA) based on experimental plots as cases with year, Scots pine tree-ring width (TRW), intrinsic water-use efficiency (iWUE) and monthly leaf litter production of the same year than tree-ring formation (Aug, Sep, Oct, Nov). (B) PCA based on experimental plots as cases with year, TRW and iWUE of Scots pine, and nutrient contents $\left(\mathrm{N}_{-3}, \mathrm{P}_{-3}, \mathrm{~K}_{-3}\right)$ and stoichiometry $\left(\mathrm{N}_{2} \mathrm{P}_{-3}, \mathrm{~N}_{\mathrm{K}} \mathrm{K}_{-3}, \mathrm{P}: \mathrm{K}_{-3}\right)$ of overall leaf litter reaching forest floor three years prior tree-ring formation. Axes represent first and second principal components (PCs); in brackets, the amount of explained variation by each PC is shown. Both sites were analyzed together. 


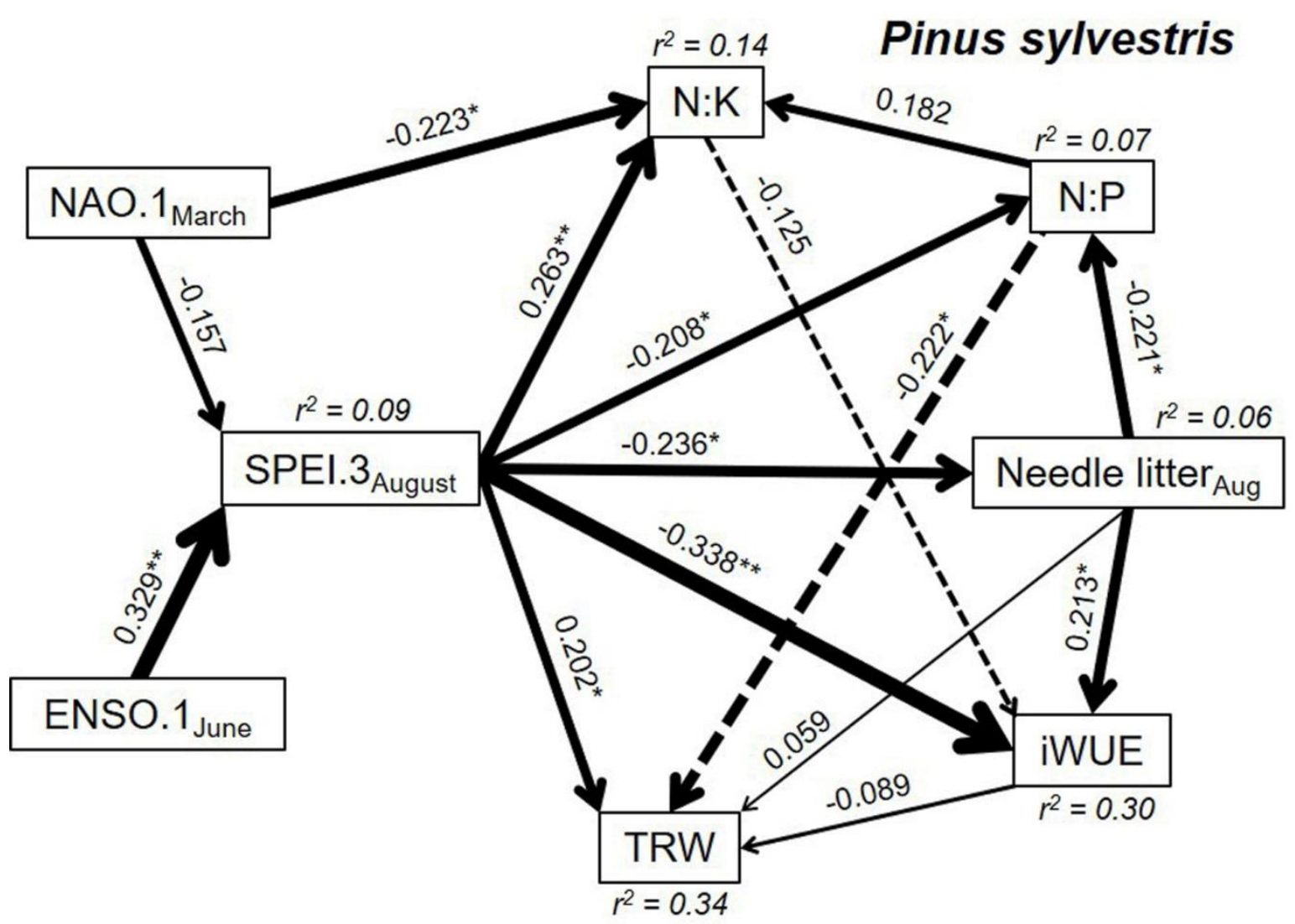

Figure 8. Mechanistic representation of the climate-leaf litter dynamics-tree-ring information relationships in Scots pine (Pinus sylvestris). Results of the Structural Equation Models (SEMs) exploring the effects of large-scale circulation patterns (NAO and ENSO) on standardized precipitation evaporation index (SPEI), the effects of SPEI on leaf litter seasonality of Scots pine and leaf litter stoichiometry considering the joint contribution of both species, and the effects of leaf litter dynamics on Scots pine tree-ring width (TRW) and intrinsic water-use efficiency (iWUE). Variables included in the model are trendless components. Global goodness of fit of the entire model is $C_{(\mathrm{df}=24)}=21.37(p=0.617)$ (Lefcheck 2016). Arrow thickness is proportional to the standardized regression coefficient's magnitude (showed beside each arrow). Significant coefficients are marked with asterisks (* $=p<0.05 ; * *=p<0.01)$. Solid arrows represent relationships among variables measured in the same year and dash arrows indicate a time lag of 3 years between leaf fall and tree-ring formation of pine trees (i.e. indirect relationship through decomposition and nutrient release processes). R-squared values of individual models are shown. 